\title{
A phosphate-bearing pegmatite from Lutomia and its relationships to other pegmatites of the Góry Sowie Block, southwestern Poland
}

\author{
Adam WŁODEK'1, Anna GROCHOWINA', Bożena GOŁĘBIOWSKA'1, Adam PIECZKA ${ }^{1 *}$ \\ ${ }^{1}$ AGH University of Science and Technology, Department of Mineralogy, Petrography and Geochemistry, Mickiewicza 30, 30-059 Kraków, \\ Poland; pieczka@agh.edu.pl \\ *Corresponding author
}

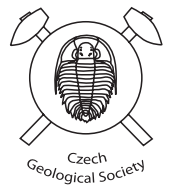

\begin{abstract}
A geochemically primitive, moderately fractionated, LCT pegmatite from Lutomia (Góry Sowie Block, SW Poland) has been characterized in respect of the primary and secondary phosphate assemblages. The pegmatite crystallized from anatectic granitic magmas mobilized by $\mathrm{M}_{2-3}$ metamorphism at $\sim 370-380 \mathrm{Ma}$. Three phosphate assemblages had a different origin: (1) the primary, magmatic one [graftonite-(I)-beusite-(I) + triphylite \pm sarcopside], (2) a secondary, metasomatic one [Ca-rich graftonite-(II) - Ca-rich beusite-(II) + wolfeite/triploidite/staněkite + hagendorfite/alluaudite + kryzhanovskite \pm a Ca-bearing phosphate close to ferromerrillite + fluorapatite], and (3) a secondary, hydrothermal and weathering one [ferrisicklerite \pm heterosite + phosphoferrite-kryzhanovskite + ludlamite + vivianite \pm hureaulite + earlshannonite-whitmoreite + strunzite-ferrostrunzite + beraunite + dufrénite + jahnsite-(CaMnFe), -(CaMnMn) and $-(\mathrm{MnMnMn})+$ landesite + fairfieldite $+\mathrm{Mn}^{2+}$-bearing hydroxyapatite].

The magmatic assemblage resulted from the breakdown of a primary, high-T, Ca- and Li-enriched graftonite-like phase. It was induced by cooling and elevated incompatible $\mathrm{Ca}, \mathrm{Na}, \mathrm{Li}$ and $\mathrm{F}$ concentrations. The metasomatic assemblage reflects the destabilization of the magmatic phosphates and their Ca- and Na-metasomatism by a high-T fluid connected with a $\mathrm{PO}_{4}$-bearing melt, which previously had evolved along with graftonite-(I)-beusite-(I). The assemblage of secondary, hydrothermal and weathering, phosphates was a result of lower T alteration by hydrothermal fluids and meteoric water by both topotactic Fe and Mn oxidation as well gradual hydration and Fe oxidation. Taken together, the Lutomia pegmatite has been compared to the phosphate-bearing pegmatite at Michałkowa and the mixed NYF + LCT, $\mathrm{PO}_{4}$-poor pegmatitic system of Piława Górna.
\end{abstract}

Keywords: phosphate-bearing pegmatite, LCT anatectic pegmatite, Lutomia, Poland

Received: 16 October 2013; accepted: 25 November 2014; handling editor: Milan Novák

The online version of this article (doi: 10.3190/jgeosci.185) contains supplementary electronic material.

\section{Introduction}

The Góry Sowie Block (GSB) in Lower Silesia, SW Poland, is a region with an old tradition of pegmatite exploitation. In the $18^{\text {th }}$ and $19^{\text {th }}$ centuries, the pegmatites were quarried by Germans as a source of raw quartz and feldspars. During the mining, small quantities of phosphate minerals were occasionally found. Fiedler (1863) reported the presence of triplite in a railway cut north of Piława Górna, whilst Websky (1868) discovered a pegmatite at Michałkowa (= Michelsdorf) with, at that time, an unknown phosphate mineral named sarcopside, associated with hureaulite, vivianite and an apatite-group mineral. The end of mining activity in the area after WW II has limited modern mineralogical studies to a few small in situ occurrences, and the GSB pegmatites were largely ignored up to the beginning of the current century. Only Pieczka et al. (2003) gave brief indications of the Li-bearing mineralization present in the GSB region, observed as lamellar intergrowths of ferrisicklerite with graftonite and sarcopside at Lutomia, as well as green elbaite found in the vicinity of Gilów (Pieczka et al. 2004).
Moreover, Łodziński and Sitarz (2009) studied graftonite and sarcopside from Michałkowa.

The aim of this paper is a description of the Lutomia pegmatite, as the currently best representative of phosphate pegmatitic mineralization in the GSB, and an evaluation of its relationships to the other important pegmatites in the unit. Particular attention is being paid to textural relations and chemical compositions of the minerals that reflect the geochemical evolution of the pegmatiteforming melts.

\section{Geological setting}

The Góry Sowie Block is a relatively large geological unit $\left(c .650 \mathrm{~km}^{2}\right)$ in the central Sudetes, in the northeastern part of the Bohemian Massif, southwestern Poland (Fig. 1). It is formed mainly of oligoclase-biotite paragneisses, migmatites and orthogneisses, with minor bodies of anatectic granites and pegmatites, metabasites, granulites, eclogites, marbles and calc-silicate rocks (Polański 1955; Grocholski 1967; Morawski 1973; 


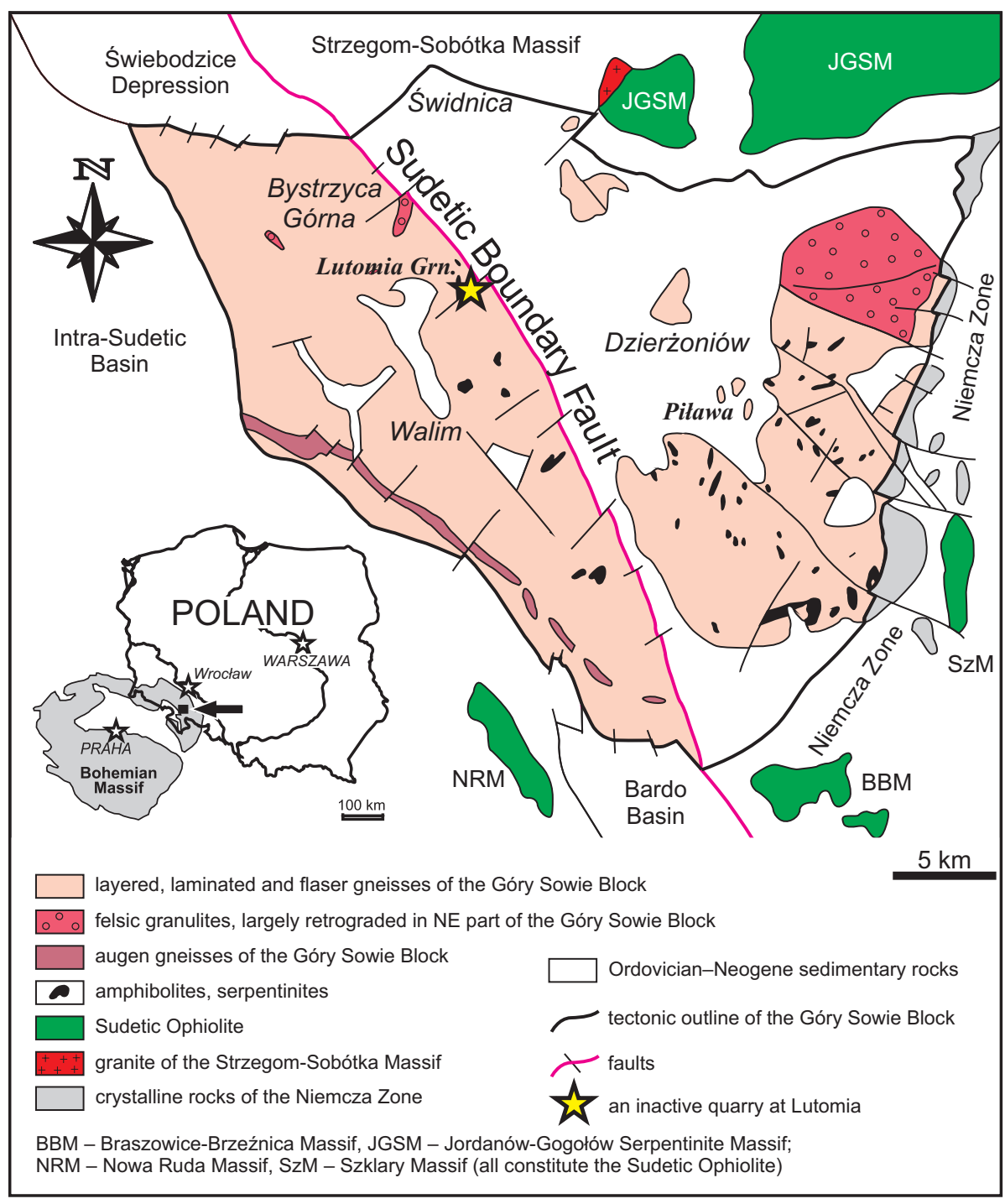

Fig. 1 Geological map of the Góry Sowie Block (after Szuszkiewicz et al. 2013).
Kryza 1981; Żelaźniewicz 1987; Gunia 1997; Ilnicki et al. 2010). A metapelitic-metapsammitic sequence of late Proterozoic to early Cambrian age, locally intruded by I-type, calc-alkaline rocks 518-480 Ma old, and tholeiitic basalts, was a protolith to the gneisses and amphibolites (Gunia 1985; Kröner and Hegner 1998; Kryza and Fanning 2007; Ilnicki et al. 2012). The complex first underwent an upper amphibolite- to granulite-facies metamorphism ( $\mathrm{T} \sim 900-1000^{\circ} \mathrm{C}, \mathrm{P} \sim 15-20 \mathrm{kbar}$ ) at 402-395 Ma (Brueckner et al. 1996; Żelaźniewicz 1997; O’Brien et al. 1997; Bröcker et al. 1998; Timmermann et al. 2000; Aftalion and Bowes 2002; Gordon et al. 2005; Kryza and Fanning 2007; Ilnicki et al. 2011). It was followed by five younger amphibolite-facies tectonothermal events $\left(D_{1}-D_{5}\right) \sim 385-370$ Ma connected with metamorphism $\left(\mathrm{M}_{1}-\mathrm{M}_{5}\right)$ (Kryza 1981; Żelaźniewicz 1987, 1990, 1997). The $M_{2}-M_{3}$ peak of this younger metamorphism at $775-910^{\circ} \mathrm{C}$ and $6.5-8.5 \mathrm{kbar}$ (Brueckner et al. 1996; O’Brien et al. 1997; Kryza and Fanning 2007), triggered anatectic melting and possible igneous activity at deeper crustal levels. It was manifested by pervasive migmatization, metamorphic segregation, and injections of granite-like magma in gneisses, migmatites, metabasite rocks and granulites at the $\mathrm{D}_{3}$ and $\mathrm{D}_{4}$ decompression stage. These injections have the form of fine secretions concordant with the host structures, and discordant, N-trending pegmatite dikes (van Breemen et al. 1988; Żelaźniewicz 1990; Bröcker et al. 1998; Timmermann et al. 2000; Aftalion and Bowes 2002; Gordon et al. 2005). Rapid exhumation of the GSB connected with progressive decompression, and $\mathrm{M}_{5}$ retrograde (middle to lower amphibolite-facies) metamorphism, induced further partial melting of rocks in deeper parts of the crust. The absolute age of the dikes ( $370 \pm 4 \mathrm{Ma}$, van Breemen et al. 1988; 383-370 Ma Timmermann et al. 2000), their frequency in the GSB and near absence from the adjacent units unequivocally prove that the pegmatites were coeval with the younger stage of the GSB metamorphism. 
Novák (2005), summarizing the state of knowledge of the Bohemian Massif pegmatites, tentatively classified the GSB pegmatites as the beryl subtype of the LCT (lithium-cesium-tantalum) petrogenetic family of Černý and Ercit (2005). However, mineral compositions in the largest co-genetic pegmatite system of the GSB exposed in the Piława Górna quarry, disclose its hybrid NYF (niobium-yttrium-fluorine) + LCT signature (Pieczka et al. 2013; Szuszkiewicz et al. 2013). The pegmatites contain numerous $\mathrm{Y}+$ $R E E$ accessory phases, e.g., samarskite-, euxenite-, fergusonite-, gadolinite-group minerals, and (Y,REE)bearing pyrochlore-supergroup minerals, considered as important indicators of the NYF petrogenetic family. On the other hand, very strongly fractionated units located sometimes within axial parts of the thickest dikes can contain elbaite-liddicoatite-rossmanite tourmaline, pollucite, spodumene, Cs-bearing beryl and Li-micas, i.e. minerals typical of the LCT family.

\section{The Lutomia pegmatite}

Lutomia is a village located in the Fore-Sudetic part of the GSB, c. $5 \mathrm{~km} \mathrm{SE}$ of Świdnica, $\sim 60 \mathrm{~km} \mathrm{SW}$ of Wrocław, close to the Sudetic Boundary Fault (Fig. 1). In the south-western mountainous part of the village there is a small, abandoned quarry. Here, amphibolites and migmatites are cut by a relatively large, discordant, vertical pegmatite vein, c. $20 \mathrm{~m}$ long and up to $1 \mathrm{~m}$ thick, showing one nest-like thickening up to $2 \mathrm{~m}$ across, and a few smaller offshoots. The main pegmatite vein, especially in the nest, displays a visible zoning. A very thin, fine- to medium-grained border zone is followed by a coarser grained wall zone. Both are composed mainly of quartz, sodic plagioclase, partially altered 'biotite' in places with signs of sillimanitization (fibrolite), subordinate K-feldspar and tiny crystals of grass-green fluorapatite (Fig. 2a-c). The wall zone changes progressively into an intermediate zone formed of quartz-feldspar graphic intergrowths with increasing amounts of K-feldspar, containing in places small muscovite-tourmaline aggregates with rare, scattered phosphates. The blocky feldspar zone is composed of blocky orthoclase, frequently showing a two-stage growth-zoning, plagioclase, almost completely chloritized biotite declining inwards, muscovite books, occasionally black tourmaline and interstitial quartz. The zone is followed by massive albite with rare phosphate nodules disseminated locally (Fig. 2d-f). No quartz core was observed. Tiny inclusions of monazite-(Ce), xenotime-(Y), uraninite, pyrite, Cd-wurtzite or sphalerite, cuprite, chalcocite or covellite and native copper, have been recognized within the nodules.

\section{Mineralogy of the phosphate assemblage}

\subsection{Textural relationships}

Three phosphate assemblages can be distinguished based on textural relationships: (1) primary magmatic phosphates, (2) secondary metasomatic phosphates, and (3) secondary hydrothermal and weathering phosphates (Tab. 1).

\subsubsection{Primary, magmatic phosphates}

The assemblage of primary phosphates, graftonitetriphylite-sarcopside, represents the bulk of the phos-

Tab. 1 Phosphate minerals in the Lutomia pegmatite

\begin{tabular}{|c|c|}
\hline & magmatic \\
\hline Monazite-(Ce) & $\mathrm{CePO}_{4}$ \\
\hline Xenotime-(Y) & $\mathrm{YPO}_{4}$ \\
\hline Graftonite & $\left(\mathrm{Fe}^{2+}, \mathrm{Mn}^{2+}, \mathrm{Ca}, \mathrm{Mg}\right)_{3}\left(\mathrm{PO}_{4}\right)_{2}$ \\
\hline Beusite & $\left(\mathrm{Mn}^{2+}, \mathrm{Fe}^{2+}, \mathrm{Ca}, \mathrm{Mg}\right)_{3}\left(\mathrm{PO}_{4}\right)_{2}$ \\
\hline Sarcopside & $\left(\mathrm{Fe}^{2+}, \mathrm{Mn}^{2+}, \mathrm{Mg}\right)_{3}\left(\mathrm{PO}_{4}\right)_{2}$ \\
\hline Triphylite & $\mathrm{Li}\left(\mathrm{Fe}^{2+}, \mathrm{Mn}^{2+}\right)\left(\mathrm{PO}_{4}\right)$ \\
\hline \multicolumn{2}{|c|}{ Secondary: metasomatic } \\
\hline Graftonite (Ca-rich) & $\left(\mathrm{Fe}^{2+}, \mathrm{Mn}^{2+}, \mathrm{Ca}, \mathrm{Mg}\right)_{3}\left(\mathrm{PO}_{4}\right)_{2}$ \\
\hline Beusite (Ca-rich) & $\left(\mathrm{Mn}, \mathrm{Fe}^{2+}, \mathrm{Ca}, \mathrm{Mg}\right)_{3}\left(\mathrm{PO}_{4}\right)_{2}$ \\
\hline Wolfeite & $\mathrm{Fe}_{2}^{2+}\left(\mathrm{PO}_{4}\right)(\mathrm{OH})$ \\
\hline Triploidite & $\mathrm{Mn}_{2}^{2+}\left(\mathrm{PO}_{4}\right)(\mathrm{OH})$ \\
\hline Staněkite & $\mathrm{Fe}^{3+} \mathrm{Mn}^{2+}\left(\mathrm{PO}_{4}\right) \mathrm{O}$ \\
\hline Hagendorfite & $(\mathrm{Na}, \mathrm{Ca})\left(\mathrm{Mn}, \mathrm{Fe}^{2+}\right)\left(\mathrm{Fe}^{2+}, \mathrm{Fe}^{3+}, \mathrm{Mg}\right)_{2}\left(\mathrm{PO}_{4}\right)_{3}$ \\
\hline Ferrohagendorfite & $(\mathrm{Na}, \mathrm{Ca})\left(\mathrm{Fe}^{2+}, \mathrm{Mn}\right)\left(\mathrm{Fe}^{2+}, \mathrm{Fe}^{3+}, \mathrm{Mg}\right)_{2}\left(\mathrm{PO}_{4}\right)_{3}$ \\
\hline Alluaudite & $(\mathrm{Na}, \mathrm{Ca})\left(\mathrm{Mn}, \mathrm{Mg}, \mathrm{Fe}^{2+}\right)\left(\mathrm{Fe}^{3+}, \mathrm{Mn}^{2+}\right)_{2}\left(\mathrm{PO}_{4}\right)$ \\
\hline Kryzhanovskite & $\left(\mathrm{Fe}^{3+}, \mathrm{Mn}^{2+}\right)_{3}\left(\mathrm{PO}_{4}\right)_{2}\left(\mathrm{OH}, \mathrm{H}_{2} \mathrm{O}\right)_{3}$ \\
\hline Phase-(A) & $\mathrm{Ca}_{9} \mathrm{NaFe}^{2+}\left(\mathrm{PO}_{4}\right)_{7}$ \\
\hline A dickinsonite-group minera & \\
\hline Fluorapatite (manganoan) & $(\mathrm{Ca}, \mathrm{Mn})_{5}\left(\mathrm{PO}_{4}\right)_{3} \mathrm{~F}$ \\
\hline \multicolumn{2}{|c|}{ Secondary: hydrothermal } \\
\hline Ferrisicklerite & $\mathrm{Li}_{1-\mathrm{x}}\left(\mathrm{Fe}^{3+}, \mathrm{Mn}^{2+}\right)\left(\mathrm{PO}_{4}\right)$ \\
\hline Heterosite & $\left(\mathrm{Fe}^{3+}, \mathrm{Mn}^{3+}\right)\left(\mathrm{PO}_{4}\right)$ \\
\hline Phosphoferrite & $\mathrm{Fe}_{3}^{2+}\left(\mathrm{PO}_{4}\right)_{2} \cdot 3 \mathrm{H}_{2} \mathrm{O}$ \\
\hline Ludlamite & $\mathrm{Fe}_{3}^{2+}\left(\mathrm{PO}_{4}\right)_{2} \cdot 4 \mathrm{H}_{2} \mathrm{O}$ \\
\hline Vivianite & $\mathrm{Fe}_{3}^{2+}\left(\mathrm{PO}_{4}\right)_{2} \cdot 8 \mathrm{H}_{2} \mathrm{O}$ \\
\hline Fairfieldite & $\mathrm{Ca}_{2} \mathrm{Mn}^{2+}\left(\mathrm{PO}_{4}\right)_{2} \cdot 2 \mathrm{H}_{2} \mathrm{O}$ \\
\hline Hureaulite & $\mathrm{Mn}_{5}^{2+}\left(\mathrm{PO}_{3} \mathrm{OH}\right)_{2}\left(\mathrm{PO}_{4}\right)_{2} \cdot 4 \mathrm{H}_{2} \mathrm{O}$ \\
\hline Kryzhanovskite & $\left(\mathrm{Fe}^{3+}, \mathrm{Mn}^{2+}\right)_{3}\left(\mathrm{PO}_{4}\right)_{2}\left(\mathrm{OH}, \mathrm{H}_{2} \mathrm{O}\right)_{3}$ \\
\hline Earlshannonite & $\mathrm{Mn}^{2+} \mathrm{Fe}_{2}^{3+}\left(\mathrm{PO}_{4}\right)_{2}(\mathrm{OH})_{2} \cdot 4 \mathrm{H}_{2} \mathrm{O}$ \\
\hline Whitmoreite & $\mathrm{Fe}^{2+} \mathrm{Fe}_{2}^{3+}\left(\mathrm{PO}_{4}\right)_{2}(\mathrm{OH})_{2} \cdot 4 \mathrm{H}_{2} \mathrm{O}$ \\
\hline Strunzite & $\mathrm{Mn}^{2+} \mathrm{Fe}_{2}^{3+}\left(\mathrm{PO}_{4}\right)_{2}(\mathrm{OH})_{2} \cdot 6 \mathrm{H}_{2} \mathrm{O}$ \\
\hline Ferrostrunzite & $\mathrm{Fe}^{2+} \mathrm{Fe}_{5}^{3+}\left(\mathrm{PO}_{4}\right)_{4}(\mathrm{OH})_{2} \cdot 6 \mathrm{H}_{2} \mathrm{O}$ \\
\hline Jahnsite-(CaMnFe) & $\mathrm{CaMn}^{2+} \mathrm{Fe}^{2+} \mathrm{Fe}_{2}^{3+}\left(\mathrm{PO}_{4}\right)_{4}(\mathrm{OH})_{2} \cdot 8 \mathrm{H}_{2} \mathrm{O}$ \\
\hline Jahnisite-(CaMnMn) & $\mathrm{CaMn}^{2+} \mathrm{Mn}^{2+} \mathrm{Fe}^{3+}{ }_{2}\left(\mathrm{PO}_{4}\right)_{4}(\mathrm{OH})_{2} \cdot 8 \mathrm{H}_{2} \mathrm{O}$ \\
\hline Jahnsite-(MnMnMn) & $\mathrm{Mn}^{2+} \mathrm{Mn}^{2+} \mathrm{Mn}^{2+} \mathrm{Fe}_{2}^{3+}\left(\mathrm{PO}_{4}\right)_{4}(\mathrm{OH})_{2} \cdot 8 \mathrm{H}_{2} \mathrm{O}$ \\
\hline Beraunite & $\mathrm{Fe}^{2+} \mathrm{Fe}_{2}^{3+}\left(\mathrm{PO}_{4}\right)_{2}(\mathrm{OH})_{5} \cdot 4 \mathrm{H}_{2} \mathrm{O}$ \\
\hline Dufrénite & $\mathrm{Fe}^{2+} \mathrm{Fe}_{4}^{3+}\left(\mathrm{PO}_{4}\right)_{3}(\mathrm{OH})_{5} \cdot 2 \mathrm{H}_{2} \mathrm{O}$ \\
\hline Landesite & $(\mathrm{Mn}, \mathrm{Mg})_{9} \mathrm{Fe}_{3}^{3+}\left(\mathrm{PO}_{4}\right)_{8}(\mathrm{OH})_{3} \cdot 9 \mathrm{H}_{2} \mathrm{O}$ \\
\hline Hydroxyapatite (manganoan & )$(\mathrm{Ca}, \mathrm{Mn})_{5}\left(\mathrm{PO}_{4}\right)_{3} \mathrm{OH}$ \\
\hline
\end{tabular}



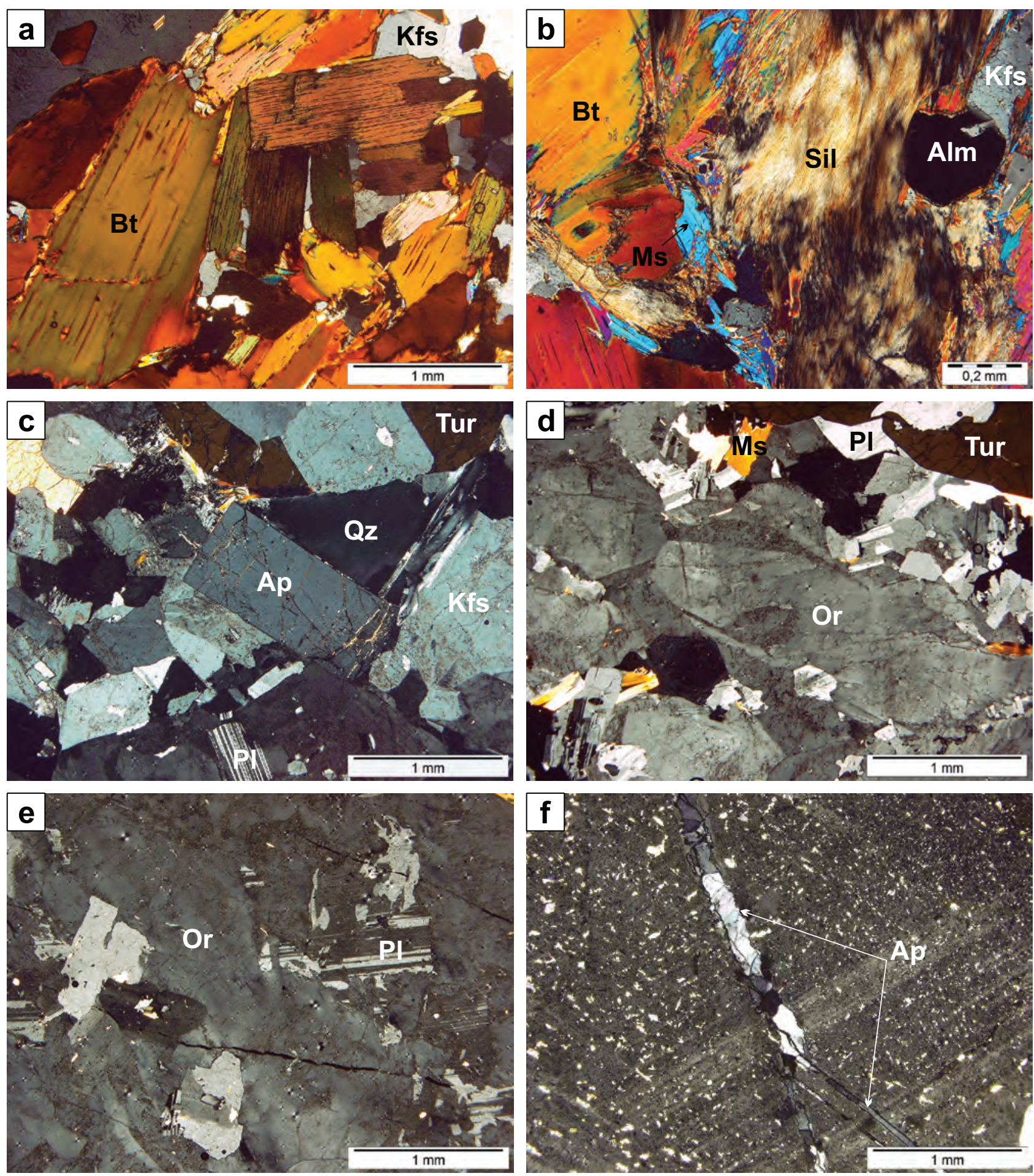

Fig. 2 Textural relationships among main rock-forming minerals in the Lutomia pegmatite: a - 'biotite' laths in the border zone of the pegmatite, accompanied by K-feldspar and quartz; b - intense sillimanitization of 'biotite' in a quartz-feldspar-bearing apophysis; $\mathbf{c}$ - euhedral apatite (green in hand specimen) from the border zone; $\mathbf{d}$ - two-stage, discontinuously zoned orthoclase, associated with plagioclase, a white mica and tourmaline in transition to the blocky feldspar zone; $\mathbf{e}$ - blocky orthoclase, containing relics of plagioclase; $\mathbf{f}$ - an intensively sericitized plagioclase monocryst from the massive albite zone, the main host of the phosphate nodules, cross-cut by veinlets of secondary apatite (colorless to pale blue in hand specimen). Abbreviations: Alm - almandine, Ap - an apatite-group mineral, $\mathrm{Bt}$ - a biotite-group mineral, Kfs - K-feldspar, Ms - muscovite, Or orthoclase, $\mathrm{Pl}$ - a plagioclase-group mineral, Qz - quartz, Sil - sillimanite, Tur - a tourmaline-supergroup mineral. 
phate nodules, reaching $5 \mathrm{~cm}$ across. The phosphates commonly occur as lamellar intergrowths of pale pink graftonite with light greenish triphylite and sarcopside, formed by exsolution of triphylite and sarcopside from the graftonite host; granular aggregates are rarer (Figs $3-5$ ). Tiny (usually $<10-20 \mu \mathrm{m}$ in length) inclusions of two common REE-bearing phosphates, monazite-(Ce) prevailing over xenotime-(Y), are disseminated within the lamellar phosphates.

Graftonite, evolving to beusite [graftonite-(I)-beusite(I)], is the principal mineral in the intergrowths forming plates up to $1 \mathrm{~mm}$ thick, whereas triphylite is the main exsolved phase. Triphylite (or secondary ferrisicklerite as a product of triphylite topotactic oxidation) commonly forms a set of almost parallel lamellae with local bulges, constrictions and multipronged splits, tapering out towards terminations, with thickness attaining several hundred micrometers (Fig. 4). In the outermost portions of the intergrowths, the continuity of the lamellae can be broken and each of the Li-bearing minerals can form small lenticles (Fig. 3a). Although triphylite and ferrisicklerite can occur in two succeeding lamellae separated by graftonite (Fig. 4a), no relics of triphylite within ferrisicklerite have been found. On the other hand, rod-shaped individuals, even over $1 \mathrm{~mm}$ in cross section, were observed in some phosphate nodules (Fig. 4b, d). Triphylite lamellae, similarly to graftonite, have distinct preferential optical orientations; however, neither in triphylite, nor in graftonite the orientations are uniform (Fig. 3d-e).

Sarcopside occurs only locally as needle-like lamellae in triphylite or ferrisicklerite, up to $50 \mu \mathrm{m}$ thick and several hundred $\mu \mathrm{m}$ long (Figs 3c, 4). The sarcopside inclusions are distinct from thin lamellae of graftonite, sometimes also embedded in the triphylite-ferrisicklerite host, by their spatial arrangement. Sarcopside commonly occurs as one or two independent sets of diagonally arranged and crisscrossing needles, whilst the graftonite lamellae, only 5-20 $\mu \mathrm{m}$ thick and several hundred $\mu \mathrm{m}$ long, are arranged parallel to the orientation of the principal graftonite-triphylite (ferrisicklerite) intergrowths (Fig. 4c). Lamellae of sarcopside commonly taper toward terminations; however, in some triphylite (ferrisicklerite) rods they adhere to the surrounding graftonite by a wider termination and grow toward the interior tapering progressively (Fig. 4d).

Granular to granoblastic aggregates of graftonite and ferrisicklerite with substantially rarer sarcopside, and with signs of intense metasomatism, occur only in deformation zones observed on microscopic scale, cutting the assemblage of the primary lamellar phosphates (Fig. 5). Pseudoplaty to subhedral grains of graftonite and ferrisicklerite are usually only several tens of micrometers long and 20-50 $\mu \mathrm{m}$ thick, often with an almost parallel arrangement imitating lamellar orientation in the primary intergrowths. Sarcopside of the granular aggregates, with a clearly visible cleavage, expands along the veinlets. In contrast to sarcopside of the lamellar assemblage, granular sarcopside does not exhibit any close relationship with ferrisicklerite. Elongated grains of the mineral filling the veinlets cut not only ferrisicklerite plates, but also the intercalated graftonite-(I) bands (Fig. 5d). Grains of sarcopside are commonly partly overgrown by Ca-bearing graftonite and alluaudite-group minerals.

\subsubsection{Metasomatic phosphates}

The metasomatic assemblage forms thin veinlets cutting the primary lamellar phosphates and irregular zones at the nodule borders, very often with superimposed hydrothermal alteration to lower temperature, hydrated and oxidized phosphates (Fig. 5). The assemblage comprises Ca-rich graftonite evolving to Ca-rich beusite [graftonite(II)-beusite-(II)], alluaudite- and wagnerite-group minerals, and kryzhanovskite, a Ca-bearing mineral with composition close to extraterrestrial ferromerrillite and fluorapatite at the outermost nodule rim. Moreover, relics of a dickinsonite-like mineral accompanied by wolfeite were found in masses of secondary phosphates abundant in the contact zone with albite.

Ca-rich graftonite evolving to Ca-rich beusite represents a specific member in the graftonite-beusite series, close to the composition of $\mathrm{CaFeMn}\left(\mathrm{PO}_{4}\right)_{2}$. It was first noted in the Yellowknife pegmatite, Canada (Wise and Černý 1990), where it forms lamellar intergrowths with triphylite; a few Canadian and Swedish pegmatites followed (Černý et al. 1998; Smeds et al. 1998). Everywhere, the mineral occurred as a magmatic phase, forming lamellar intergrowths with sarcopside and triphylite. In the Lutomia pegmatite, Ca-rich graftonite evolving to Ca-rich beusite forms irregular rims, up to a few micrometers thick, around subhedral grains of graftonite-(I)-beusite-(I) in the micro-deformation zones. Sometimes it fills completely interstices between the grains. The phase also forms subhedral grains, up to a few tens of micrometers across, in the outermost, marginal zones of the veinlets. Less frequently, it occurs as small isolated patches within graftonite-(I)-beusite-(I), commonly without any textural relationship to secondary phosphates filling the veinlets (Fig. 5a-d). Occasionally, large relics of beusite-(II), overgrown with alluaudite and a jahnsite-group mineral, were observed in masses of altered phosphates in the outer zones of a few nodules (Fig. 5e). Such a mode of graftonite-(II)-beusite-(II) occurrence suggests a formation by Ca-metasomatic replacement of the granular graftonite-(I)-beusite-(I) along the grain boundaries through intergranular diffusion of a metasomatic fluid into the lamellar host, and crystalliza- 

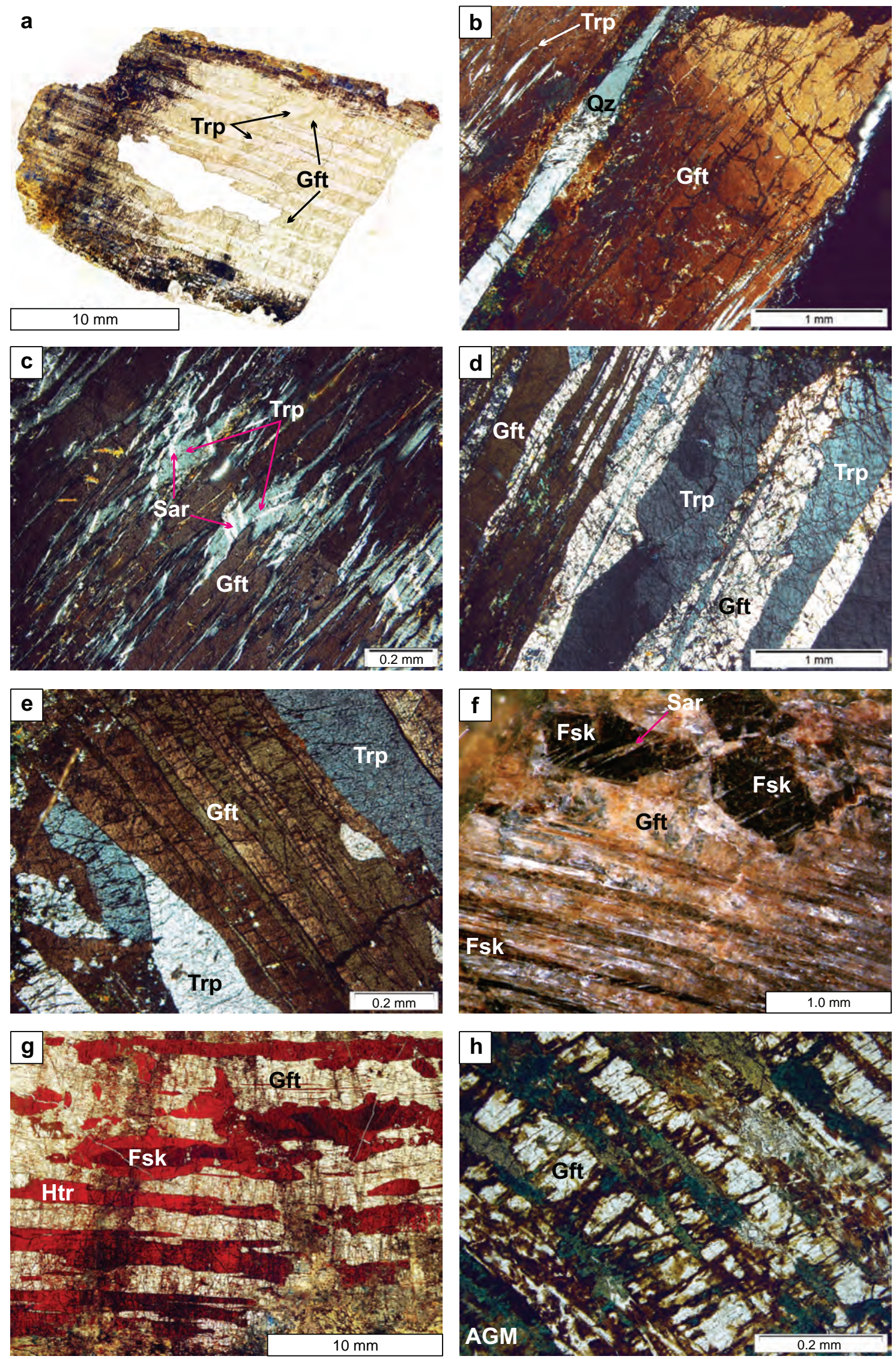

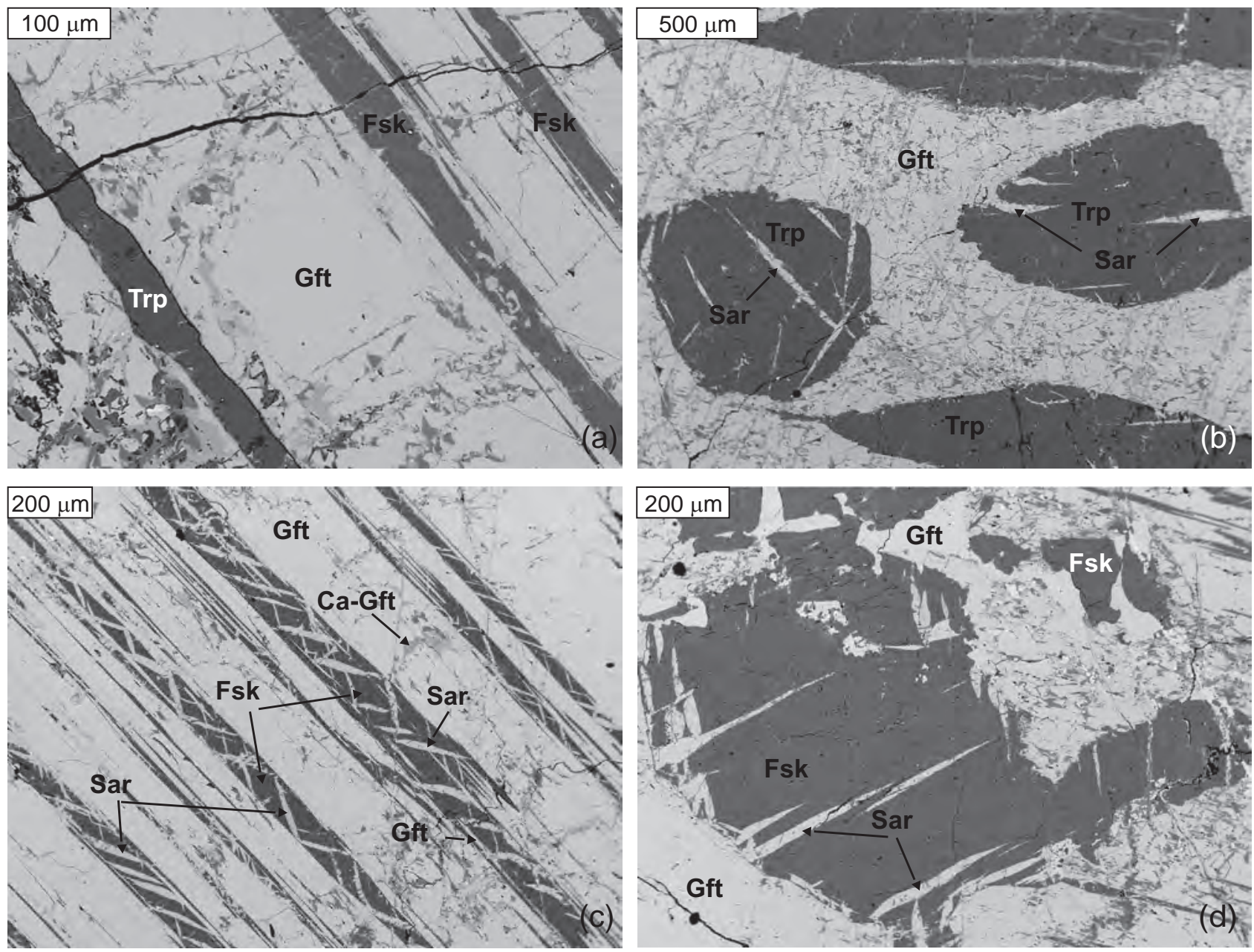

Fig. 4 Back-scattered-electron images of the primary phosphates: a - lamellar intergrowths of graftonite-(I) with triphylite and ferrisicklerite; $\mathbf{b}-$ euhedral crystals of triphylite with exsolved sarcopside within graftonite-(I); c - lamellar intergrowths of graftonite-(I) and ferrisicklerite containing diagonally-arranged lamellae of sarcopside, and parallel lamellae of graftonite-(I) evolving to beusite-(I); d - euhedral crystals of ferrisicklerite with sarcopside lamellae within graftonite-(I). Abbreviations: Fsk - ferrisicklerite, Gft - graftonite-(I), Ca-Gft - graftonite-(II), Sar - sarcopside, Trp - triphylite.

Fig. 3 Photomicrographs of the Lutomia phosphates: a - a fragment of a common phosphate nodule, showing the primary lamellar intergrowths of triphylite with sarcopside, altered in the outermost zone to secondary phosphates (polarizing microscope, plane-polarized light $-1 \mathrm{P}$ ); b - a zoned graftonite monocryst with rare exsolutions of triphylite (crossed-polarized light - XP); c - sarcopside exsolved from triphylite within the graftonite host (XP); d-e - lamellar intergrowths of graftonite with triphylite. Both minerals display varying optical orientations in the lamellae (XP); $\mathbf{f}$ - a stereomicroscope image of lamellar intergrowths of secondary ferrisicklerite, a product of topotactic oxidation of triphylite, with graftonite. Within the lamellae are embedded rods of ferisicklerite with exsolved lamellar sarcopside; $\mathbf{g}$ - lamellar intergrowths of heterosite and ferrisicklerite, as products of topotactic oxidation of triphylite, with graftonite (1P); $\mathbf{h}$ - intergrowths of secondary alluaudite-group minerals with relics of graftonite in altered, outer zone of a phosphate nodule (1P). Abbreviations: Fsk - ferrisicklerite, Gft - graftonite-(I), Htr - heterosite, Sar - sarcopside, Trp - triphylite, Qz - quartz, AGM - alluaudite-group minerals. tion from a late, residual melt on the primary, lamellar phosphates. The metasomatic origin of such graftonitebeusite is noted in the series for the first time.

Minerals of the alluaudite group (hagendorfite, ferrohagendorfite and alluaudite), along with the members of the wagnerite group and kryzhanovskite, are the most common metasomatic phosphates at Lutomia. The alluaudite-group minerals can replace lamellar triphylite and ferrisicklerite, particularly in the outermost zones of the nodules (Fig. 3h). In the deformation zones, the replacement is visible at a distance up to $100 \mu \mathrm{m}$, sometimes with preserved relics of the Li-bearing phosphates (Fig. 5b-c). Alluaudite-group minerals also form small, anhedral grains reaching 10-20 $\mu \mathrm{m}$ across, directly on the lamellar ferrisicklerite-veinlet interface, or occur as twophase, intimate symplectic intergrowths with wagneritegroup minerals, with the sizes of single individuals not exceeding $10 \mu \mathrm{m}$ (Fig. 5a-c). In the heterosite-bearing 

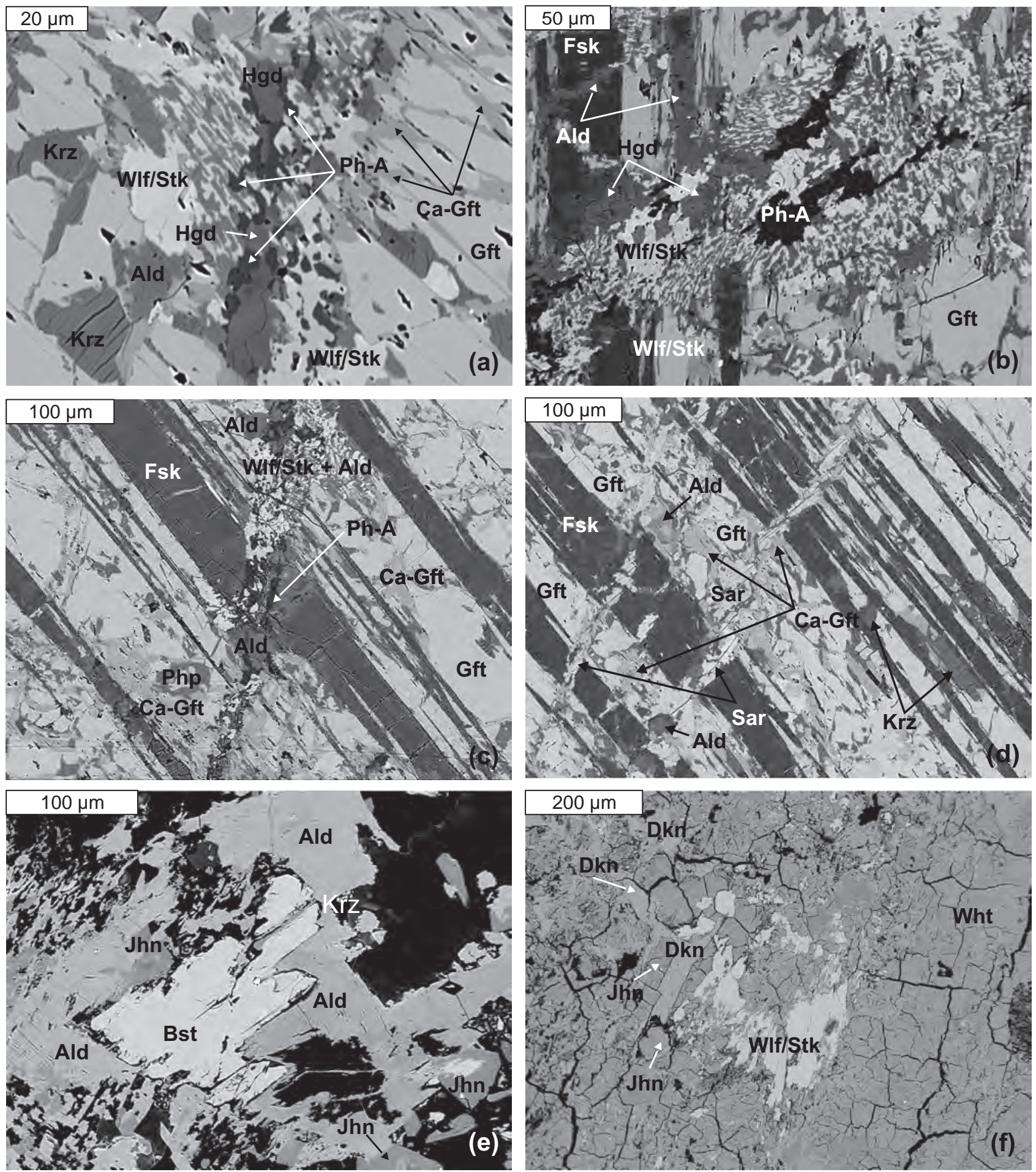

Fig. 5 Back-scattered-electron images of the metasomatic phosphates: a - Ca-metasomatism on grain boundaries of the primary graftonite-(I); b - a ferromerrillite-like mineral (phase-A) within symplectic mixture of wolfeite/staněkite with an alluaudite-group mineral; c - Na- and Cametasomatism around veinlets cutting the primary, lamellar assemblage; $\mathbf{d}$ - sarcopside filling microdeformation zones within metasomatized graftonite and ferrisicklerite lamellae; $\mathbf{e}$ - alluaudite overgrowing beusite-(II) and replaced by jahnsite-(CaMnMn); $\mathbf{f}-$ relics of a dickinsonite-like mineral and wolfeite/staněkite within secondary whitmoreite and jahnsite-(CaMnFe). Abbreviations: Ald - alluaudite, Bst - beusite-(II), Dkn - a dickinsonite-like mineral, Fsk - ferrisicklerite, Grf - graftonite-(I), Ca-Grf - graftonite-(II), Hgd - hagendorfite, Jhn - a jahnsite-group mineral, Krz - kryzhanovskite, Sar - sarcopside, Wht - whitmoreite, Wlf/Stk - wolfeite/staněkite, Ph-A - phase-A. 
nodules, alluaudite-group minerals fill fractures, usually in association with fluorapatite, Mn-bearing fluor- to hydroxyapatite and other secondary Fe-Mn phosphates. Large relic grains of alluaudite accompanied by beusite(II) and jahnsite-group minerals are sometimes common in the outer zones of some phosphate nodules (Fig. 5e).

Wolfeite, triploidite and staněkite are three representatives of the wagnerite-group minerals in the Lutomia pegmatite. The small grain sizes of wolfeite/staněkite in unaltered parts of the metasomatic veinlets, not exceeding $20-30 \mu \mathrm{m}$ for the granular individuals, and $10 \mu \mathrm{m}$ in the symplectic intergrowths, significantly limit the possibility of unequivocal distinction between the minerals (Fig. 5a-b). However in the Lutomia pegmatite, similarities with the mineral association staněkite + alluaudite + kryzhanovskite to other staněkite occurrences, e.g. the Okatjimukuja pegmatite at Karibib, Namibia (Keller et al. 1997) and the Brissago pegmatite, Switzerland (Vignola et al. 2008) makes the presence of staněkite very likely, especially in intergrowths with the alluaudite-group minerals with $\mathrm{Fe}^{3+} / \mathrm{Fe}_{\text {total }}>0.50$. Brown staněkite, often as an alteration product, is found in central parts of ferrisicklerite lamellae altered to heterosite (Figs 3g, 6a). Relics of wolfeite and/or staněkite were also observed in strongly altered outer parts of some phosphate nodules, in association with dickinsonite-like mineral, whitmoreite and a jahnsite-group mineral (Fig. 5f). Triploidite was found along with wolfeite-staněkite in the heterosite-bearing nodules, where it forms also tiny grains, commonly below $20 \mu \mathrm{m}$, and only very rarely reaching $100 \mu \mathrm{m}$. It is associated with alluaudite $(\mathrm{NaNa})$ or $(\mathrm{Na} \square)$ type or hagendorfite $(\mathrm{NaMn})$, and wolfeite or staněkite.

Kryzhanovskite represents a $\mathrm{Fe}^{3+}$-bearing member of the phosphoferrite group, usually produced by oxidation of phosphoferrite (Moore 1974; Moore and Araki 1976; Moore et al. 1980). Kryzhanovskite, accompanying the metasomatic association, forms small, anhedral grains with a clearly visible cleavage, up to $20-30 \mu \mathrm{m}$ across, disseminated separately among the granular graftonite(I)-beusite-(I), in the nearest neighborhood of the metasomatic veinlets (Fig. $5 \mathrm{a}-\mathrm{c}$ ). The mineral is absent in the axial part of the veinlets, especially within the sympletic intergrowths of the alluaudite- and wagneritegroup minerals. The secondary kryzhanovskite as an oxidation product of phosphoferrite is discussed below, along with other secondary, hydrothermal and weathering phosphates.

Phase-A, close in composition to ferromerrillite, occurs rarely in the axial part of the metasomatic veinlets and only occasionally in outer, altered zones of the nodules. It forms elongated grains, reaching $100 \times 20 \mu \mathrm{m}$, and blebs about $10 \mu \mathrm{m}$ in diameter. It is commonly associated with symplectic intergrowths of the alluaudite- and wagnerite-group minerals (Fig. 5a-c).
A dickinsonite-like mineral was found only in the form of anhedral relics reaching several tens of micrometers in size, in outer parts of the graftonite-heterosite nodule, within an aggregate of secondary phosphates composed mainly of whitmoreite and jahnsite-group minerals (Fig. 5f).

Fluorapatite (Mn-poor to Mn-bearing) forms outermost concentric rims around the phosphate nodules, commonly associated with relics of graftonite, fairfieldite, landesite, jahnsite-(CaMnFe) and -(CaMnMn), ludlamite, beraunite, dufrénite, hureaulite and Mn oxides. The contact between fluorapatite and the altered, primary lamellar assemblage preserved as remnants within the secondary phosphates, is sometimes emphasized by the presence of sulphides, mainly pyrite cubes.

\subsubsection{Secondary phosphates, produced by hydrothermal and weathering processes}

The group comprises secondary phosphate minerals formed at the expense of the magmatic or metasomatic phosphates under action of a hydrothermal fluid and meteoric water. To the group belong ferrisicklerite and heterosite as products of $\mathrm{Fe}$ oxidation and Li leaching by triphylite, then phosphoferrite, ludlamite, vivianite, fairfieldite and hureaulite containing only $\mathrm{Mn}^{2+}$ and $\mathrm{Fe}^{2+}$, kryzhanovskite, earlshannonite and whitmoreite, landesite, strunzite and ferrostrunzite, beraunite, dufrénite, jahnsite-(CaMnFe), -(CaMnMn) and -(MnMnMn), all containing some of the $\mathrm{Fe}$ as $\mathrm{Fe}^{3+}$, and finally $\mathrm{Mn}^{2+}-$ bearing hydroxyapatite. Except for ferrisicklerite and heterosite mimicking the lamellar texture of the primary triphylite, all other mentioned phosphates occur in the yellow, orange to dark brown outer zone of the nodules with partly preserved remnants of the primary lamellar texture on the macro- and micro scales, and separated dark green to dark blue patches (Fig. 3a).

Ferrisicklerite and heterosite are products of topotactic alteration of triphylite due to the oxidation of $\mathrm{Fe}^{2+}$ and $\mathrm{Mn}^{2+}$ and complete $\mathrm{Li}^{+}$leaching according to the Quensel-Mason sequence (Quensel 1937; Mason 1941), by the reaction $\square+(\mathrm{Fe}, \mathrm{Mn})^{3+} \rightarrow \mathrm{Li}^{+}+(\mathrm{Fe}, \mathrm{Mn})^{2+}$. Hence, heterosite was found in the form of lamellar intergrowths with ferrisicklerite and graftonite, but only in separate brown nodules with a sometimes visible purple-reddish tint, up to $2-3 \mathrm{~cm}$ in size. They are rarely accompanied by the typical unaltered phosphate nodules in the massive albite unit. Both minerals are easily recognized by their distinct pleochroism, light reddish to dark reddish in ferrisicklerite, and rose-red to blood-red in heterosite, exhibiting lamellar texture in the intergrowths inherited from the primary graftonite-triphylite lamellae (Fig. 3g). Topotactic $\mathrm{Fe}^{2+}$ and $\mathrm{Mn}^{2+}$ oxidation, leading finally to heterosite, resulted in the formation of irregular, crosswise 

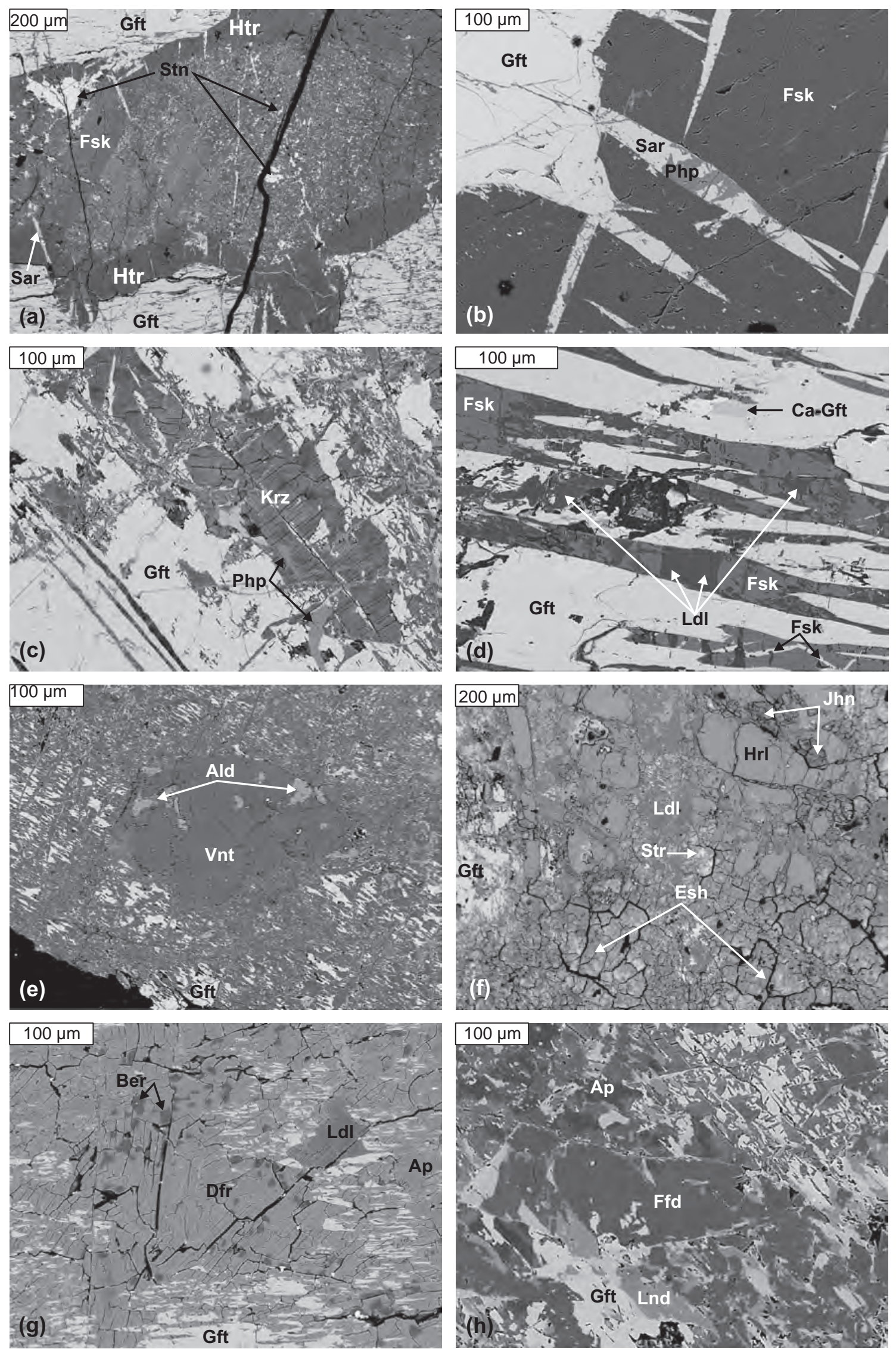
and longitudinal alteration zones within single lamellae with varying pleochroic colours (Figs 3g, 6a). They correspond to a mixture of ferrisicklerite and staněkite within central areas (dark brownish) and heterosite within outer zones (red-purple).

Phosphoferrite and kryzhanovskite, coupled by the transformation reaction $\mathrm{Fe}^{2+}{ }_{3}\left(\mathrm{PO}_{4}\right)_{2} \cdot 3 \mathrm{H}_{2} \mathrm{O} \rightarrow$ $\mathrm{Fe}^{3+}{ }_{3}\left(\mathrm{PO}_{4}\right)_{2}(\mathrm{OH})_{3}+3 \mathrm{H}^{+}$(Fransolet 2007), occur mainly in the relatively slightly altered nodule interior, where they replace both graftonite-(I) and triphylite (ferrisicklerite) or sarcopside. They also form small isolated grains up to a few tens of micrometers in size, veinlet fillings, or pseudolamellar forms, even several hundred micrometers long, as a result of ferrisicklerite or graftonite replacement (Figs $5 c-d, 6 b-c)$. Textural relationships indicate that kryzhanovskite replaced earlier phosphoferrite, and that, on the other hand, both phases are progressively replaced outward by ludlamite and other $\mathrm{Fe}^{3+}$-bearing phosphates.

Ludlamite is a common alteration product of phosphoferrite, also inheriting pseudolamellar texture from the primary triphylite (Fig. 6d). Its abundance distinctly increases in the outer zones of the strongly altered, heterosite-bearing nodules, where the mineral can form a phosphate matrix, containing anhedral grains of earshannonite-whitmoreite, strunzite and alluaudite (Fig. 6f).

Vivianite occurs locally, mainly in the outer zone of the oxidized rim, in association with graftonite relics, alluaudite and hagendorfite. It can replace ferrisicklerite, and also forms patches and fracture fillings in the altered graftonite (Fig. 6e).

Hureaulite was found only in the heterosite-bearing nodule, in association with jahnsite-(CaMnFe), jahnsite(CaMnMn), Mn-bearing hydroxyapatite and Mn oxides.

Earlshannonite, whitmoreite, strunzite and ferrostrunzite occur along with ludlamite in the outermost zone of the alteration rim in the heterosite-bearing nodule, forming individual grains up to $20-30 \mu \mathrm{m}$ across (Fig. 6f).

\footnotetext{
$\diamond$

Fig. 6 Back-scattered-electron images of the hydrothermal to weathering phosphates: a - complex internal structure of the ferrisicklerite-heterosite lamellae in the heterosite-bearing nodules; $\mathbf{b}$ - phosphoferrite replacing sarcopside; c - kryzhanovskite in altering graftonite-(I); d - ferrisicklerite replaced by ludlamite; e - vivianite replacing ferrisicklerite along with an alluaudite-group mineral; $\mathbf{f}$ - hureaulite and ludlamite in strongly altered parts of the heterosite-bearing nodules; $\mathbf{g}$ - dufrénite and beraunite replacing the primary graftonite-(I); $\mathbf{h}$ - fairfieldite and landesite with Mn-bearing hydroxyapatite in outer zones of the alteration rim. Abbreviations: Ald - an alluaudite-group mineral, Ap - an apatite-group mineral, Ber - beraunite, Dfr - dufrénite, Esh - earlshannonite, Ffd - fairfieldite, Fsk - ferrisicklerite, Gft - graftonite, Ca-Gft - graftonite-(II), Htr - heterosite, Hrl - hureaulite, Jhn - a jahnsite-group mineral, Krz - kryzhanovskite, Lnd - landesite, Ldl - ludlamite, Php - phosphoferrite, Sar - sarcopside, Stn - staněkite, Str - strunzite, Vnt - vivianite.
}

Beraunite and dufrénite are located in strongly altered zones with visible relics of the primary graftonite. They are replaced by ludlamite and Mn-bearing fluorapatite. The predominant dufrénite forms large polycrystalline aggregates with single crystals a dozen $\mu \mathrm{m}$ in size (Fig. 6g).

Jahnsite-(CaMnFe), -(CaMnMn) and -(MnMnMn) were found as tiny crystals or anhedral grains within strongly altered rims, in association with Mn-bearing hydroxyapatite, hurealite, Mn oxides and relics of altering graftonite.

Landesite and fairfieldite occur as anhedral grains in the strongly altered, outer portions of the nodules, commonly in association with Mn-bearing hydroxyl- to fluorapatite and relics of graftonite. Oval grains of fairfieldite reach $0.5 \mathrm{~mm}$ across (Fig. 6h).

Hydroxyapatite (Mn-bearing) is a second member of the apatite group occurring in the pegmatite in the form of anhedral domains, up to a few tens of micrometers in size, located within the fluorapatite rim, or accompanying relics of graftonite, fairfieldite, landesite, jahnsite$(\mathrm{CaMnFe})$ and -(CaMnMn), ludlamite, beraunite, dufrénite, hureaulite and Mn oxides in the altered rim.

\subsection{Mineral chemistry}

\subsubsection{The assemblage of primary, magmatic phosphates}

Monazite-(Ce) disseminated within phosphates of the lamellar assemblage has typical compositions with $\mathrm{Ce}>$ $\mathrm{La}>\mathrm{Nd}$, differing slightly due to the $2 L R E E^{3+} \leftarrow \mathrm{Ca}^{2+}$ $+\mathrm{U}^{4+}$ substitution (Tab. 2; see Electronic Appendix for details on analytical techniques).

Tab. 2 Representative analyses of monazite-(Ce)

\begin{tabular}{lrrrc}
\hline & \multicolumn{3}{c}{1} & \multicolumn{2}{c}{2} \\
& wt. \% & apfu & wt. \% & apfu \\
\hline $\mathrm{P}_{2} \mathrm{O}_{5}$ & 30.74 & 1.016 & 30.66 & 1.013 \\
$\mathrm{ThO}_{2}$ & 0.78 & 0.007 & 0.71 & 0.006 \\
$\mathrm{UO}_{2}$ & 2.76 & 0.024 & 6.26 & 0.054 \\
$\mathrm{Y}_{2} \mathrm{O}_{3}$ & 0.03 & 0.001 & 0.25 & 0.005 \\
$\mathrm{La}_{2} \mathrm{O}_{3}$ & 18.93 & 0.273 & 14.75 & 0.212 \\
$\mathrm{Ce}_{2} \mathrm{O}_{3}$ & 38.11 & 0.545 & 33.17 & 0.474 \\
$\mathrm{Pr}_{2} \mathrm{O}_{3}$ & 2.36 & 0.034 & 2.85 & 0.041 \\
$\mathrm{Nd}_{2} \mathrm{O}_{3}$ & 3.57 & 0.050 & 6.27 & 0.087 \\
$\mathrm{Sm}_{2} \mathrm{O}_{3}$ & 0.29 & 0.004 & 1.07 & 0.014 \\
$\mathrm{Ga}_{2} \mathrm{O}_{3}$ & b.d.l. & 0.000 & 0.43 & 0.006 \\
$\mathrm{Ho}_{2} \mathrm{O}_{3}$ & 0.11 & 0.001 & 0.06 & 0.001 \\
$\mathrm{CaO}$ & 0.85 & 0.036 & 1.96 & 0.082 \\
$\mathrm{PbO}_{\text {Total }}$ & 0.16 & 0.002 & 0.37 & 0.004 \\
\hline $\mathrm{S}, \mathrm{Si}$ & 98.70 & \multicolumn{3}{c}{98.81} \\
\hline
\end{tabular}

$\mathrm{S}, \mathrm{Si}, \mathrm{As}, \mathrm{Eu}, \mathrm{Tb}, \mathrm{Dy}, \mathrm{Er}, \mathrm{Tm}, \mathrm{Yb}$ and $\mathrm{Lu}$ are below detection limit (b.d.l.)

${ }^{1}$ normalized based on $4 \mathrm{O}$ apfu. 
Tab. 3 Representative compositions of primary phosphates and products of topotactic oxidation of triphylite (wt. \% and apfu)

\begin{tabular}{|c|c|c|c|c|c|c|c|c|c|c|c|c|}
\hline & \multicolumn{3}{|c|}{ Graftonite-(I)-Beusite-(I) } & \multicolumn{3}{|c|}{ Sarcopside } & \multicolumn{2}{|c|}{ Triphylite } & \multicolumn{3}{|c|}{ Ferrisicklerite } & \multirow{2}{*}{$\begin{array}{c}\text { Heterosite } \\
\text { lam. }\end{array}$} \\
\hline & lam. & lam. & gran. & lam. & lam. & gran. & lam. & lam. & lam. & lam. & gran. & \\
\hline & LT5 & LT1 & LT1 & LT4 & LT5 & L1d & LT1 & L2 & LT1 & lL2 & L1 & L11 \\
\hline & 2 & 8 & 24 & 9 & 1 & 90 & 5 & 60 & 87 & 27 & 15 & 33 \\
\hline $\mathrm{P}_{2} \mathrm{O}_{5}$ & 40.92 & 41.11 & 40.87 & 40.35 & 40.71 & 40.17 & 46.59 & 46.99 & 46.85 & 47.98 & 47.69 & 47.79 \\
\hline $\mathrm{Fe}_{2} \mathrm{O}_{3}$ & & & & & & & & & 31.83 & 33.97 & 34.69 & 33.65 \\
\hline $\mathrm{Mn}_{2} \mathrm{O}_{3}$ & & & & & & & & & & & & 16.15 \\
\hline $\mathrm{MnO}$ & 21.95 & 26.00 & 24.30 & 17.69 & 13.29 & 18.32 & 13.72 & 8.60 & 14.04 & 9.52 & 10.74 & \\
\hline $\mathrm{MgO}$ & 1.49 & 0.89 & 0.99 & 1.90 & 3.25 & 0.81 & 3.18 & 4.81 & 3.09 & 4.71 & 3.85 & 2.52 \\
\hline $\mathrm{CaO}$ & 4.94 & 8.08 & 6.15 & b.d.l. & b.d.l. & 0.03 & b.d.l. & b.d.l. & 0.11 & b.d.l. & 0.17 & 0.15 \\
\hline $\begin{array}{l}\mathrm{ZnO} \\
\mathrm{Li}_{2} \mathrm{O}_{\text {(calc.) }}\end{array}$ & 0.27 & 0.22 & 0.31 & b.d.l. & b.d.l. & b.d.l. & $\begin{array}{r}\text { b.d.l. } \\
9.81 \\
\end{array}$ & $\begin{array}{r}\text { b.d.l. } \\
9.89 \\
\end{array}$ & $\begin{array}{r}\text { b.d.l. } \\
4.13 \\
\end{array}$ & $\begin{array}{r}\text { b.d.l. } \\
3.75 \\
\end{array}$ & $\begin{array}{r}\text { b.d.l. } \\
3.73 \\
\end{array}$ & b.d.l. \\
\hline Total & 100.31 & 100.61 & 100.77 & 100.28 & 99.17 & 100.27 & 100.48 & 100.50 & 100.06 & 99.93 & 100.86 & 100.26 \\
\hline $\mathrm{P}^{5+}$ & 2.000 & 2.000 & 2.000 & 2.000 & 2.000 & 2.000 & 1.000 & 1.000 & 1.000 & 1.000 & 1.000 & 1.000 \\
\hline $\mathrm{Fe}^{3+}$ & & & & & & & & & 0.604 & 0.629 & 0.647 & 0.626 \\
\hline $\mathrm{Mn}^{3+}$ & & & & & & & & & & & & 0.304 \\
\hline $\mathrm{Fe}^{2+}$ & 1.485 & 1.169 & 1.361 & 1.975 & 2.034 & 2.014 & 0.576 & 0.635 & & & & \\
\hline $\mathrm{Mn}^{2+}$ & 1.073 & 1.265 & 1.190 & 0.877 & 0.653 & 0.913 & 0.295 & 0.183 & 0.300 & 0.198 & 0.225 & \\
\hline $\mathrm{Mg}^{2+}$ & 0.128 & 0.076 & 0.086 & 0.166 & 0.281 & 0.071 & 0.120 & 0.180 & 0.116 & 0.173 & 0.142 & 0.093 \\
\hline $\mathrm{Ca}^{2+}$ & 0.305 & 0.497 & 0.381 & 0.000 & 0.000 & 0.002 & 0.000 & 0.000 & 0.003 & 0.000 & 0.004 & 0.004 \\
\hline $\mathrm{Zn}^{2+}$ & 0.011 & 0.009 & 0.013 & 0.000 & 0.000 & 0.000 & 0.000 & 0.000 & 0.000 & 0.000 & 0.000 & 0.000 \\
\hline $\mathrm{Li}^{+}{ }_{\text {(calc.) }}$ & & & & & & & 1.000 & 1.000 & 0.419 & 0.371 & 0.372 & \\
\hline $\mathrm{O}^{2-}$ & 8.003 & 8.017 & 8.030 & 7.968 & 8.018 & 7.999 & 3.991 & 3.998 & 4.034 & 4.001 & 4.028 & 3.992 \\
\hline $\mathrm{Mn} /(\mathrm{Mn}+\mathrm{Fe})$ & 0.420 & 0.520 & 0.466 & 0.308 & 0.243 & 0.312 & 0.338 & 0.224 & 0.343 & 0.239 & 0.258 & 0.327 \\
\hline
\end{tabular}

${ }^{1}$ normalized to $2 \mathrm{P}$ apfu for graftonite, beusite and sarcopside, and $1 \mathrm{P}$ apfu for triphylite, ferrisicklerite and heterosite

Abbreviations: lam. - lamellar intergrowths, gran. - granular assemblage, calc. - calculated by stoichiometry

empty cell - component absent in the mineral

Graftonite hosting the lamellar triphylite-sarcopside exsolutions [graftonite-(I)] always shows a high $\mathrm{MnO}$ content (21.87 to 26.40 wt. \%), low $\mathrm{MgO}$ (0.64-1.50 wt. \%) and $\mathrm{ZnO}(<0.50$ wt. \%), with varying amounts of $\mathrm{CaO}$ (4.07-8.12 wt. \%). The $\mathrm{MnO}$ and $\mathrm{CaO}$ contents increase in thin lamellae embedded in the exsolved triphylite or secondary ferrisicklerite (Tab. 3$)$. The $\mathrm{Mn} /(\mathrm{Fe}+\mathrm{Mn}$ ) ratio of graftonite-(I) ranges from 0.42 to 0.52 , proving that $\mathrm{Mn}-\mathrm{Fe}$ fractionation in the host phosphate during formation of the intergrowths locally attained a stage with $\mathrm{Mn}$ predominance over Fe, already corresponding to beusite [beusite-(I)] (Fig. 7). The compositional range of the graftonite-beusite, $\left(\mathrm{Fe}^{2+}{ }_{1.17-1.53} \mathrm{Mn}_{1.07-1.32} \mathrm{Ca}_{0.25-0.50} \mathrm{Mg}_{0.06-0.13}\right.$ $\left.\mathrm{Zn}_{0.00-0.02}\right)\left(\mathrm{PO}_{4}\right)_{2}$, clearly indicates the dominant isovalent $\mathrm{Ca}(\mathrm{Fe})_{-1}$ and $\mathrm{Mn}(\mathrm{Fe})_{-1}$ substitutions at the $M(1)$ site (Stelle et al. 1991; Tait et al. 2013). This is probably due to the Ca- and Mn-cleaning of the triphylite host, induced by different partition coefficients of $\mathrm{Ca}^{2+}$ and $\mathrm{Mn}^{2+}$ between the graftonite structure on the one hand and triphylite and sarcopside on the other.

Triphylite and products of its topotactic oxidation with $\mathrm{Li}^{+}$leaching (ferrisicklerite and heterosite). The phosphates differ slightly in Mn contents (triphylite: 8.60-13.88 MnO, ferrisicklerite 8.95-16.01 MnO, and heterosite 15.14-21.97 $\mathrm{Mn}_{2} \mathrm{O}_{3}$, all in wt. \% - Tab. 3). The MgO content is simi- lar in triphylite and ferrisicklerite, 1.77-4.81 wt. \% and 2.21-4.83 wt. \%, respectively, and slightly lower in heterosite, $1.02-3.02 \mathrm{wt}$. \%. The $\mathrm{CaO}$ is negligible in triphylite ( $<0.03$ wt. \%), and slightly higher in ferrisicklerite (to 0.43 wt. \%) and heterosite (to 0.67 wt. \%). Zinc is always below detection. The compositional ranges of both $\mathrm{Li}$ bearing phosphates, $\left(\mathrm{Li}_{1.00} \mathrm{Fe}^{2+}{ }_{0.58-0.68} \mathrm{Mn}_{0.18-0.30} \mathrm{Mg}_{0.07-0.18}\right) \mathrm{PO}_{4}$ for triphylite, and $\left(\mathrm{Li}_{0.32-0.46} \mathrm{Fe}^{3+}{ }_{0.60-0.70} \mathrm{Mn}_{0.19-0.35} \mathrm{Mg}_{0.01-0.18}\right.$ $\left.\mathrm{Ca}_{0.00-0.01}\right) \mathrm{PO}_{4}$ for ferrisicklerite, indicate rather low and comparable $\mathrm{Mn} /(\mathrm{Mn}+\mathrm{Fe})$ ratios of $0.22-0.34$ and 0.23-0.36, respectively, whereas heterosite, $\left(\mathrm{Fe}^{3+}{ }_{0.65-0.58}\right.$ $\left.\mathrm{Mn}^{3+}{ }_{0.29-0.43} \mathrm{Mg}_{0.04-0.11} \mathrm{Ca}_{0.00-0.02} \mathrm{Zn}_{0.00-0.01}\right) \mathrm{PO}_{4}$, commonly displays a degree of Mn-Fe fractionation comparable to the parental triphylite and ferrisicklerite. Heterosite with slightly higher $\mathrm{Mn} /(\mathrm{Mn}+\mathrm{Fe})$ values reaching 0.42 was noted in association with triploidite.

Sarcopside exsolved from the triphylite host has negligible contents of $\mathrm{CaO}(<0.05$ wt. \%), moderate $\mathrm{MgO}$ comparable with triphylite and ferrisicklerite (1.84-3.32 wt. \%), and lower $\mathrm{MnO}$ contents than graftonite-(I)beusite-(I) (13.14-18.25 wt. \%) (Tab. 3). Zinc is always below detection. Compositions of the sarcopside, $\left(\mathrm{Fe}^{2+}{ }_{1.97-2.11} \mathrm{Mn}_{0.640 .91} \mathrm{Mg}_{0.16-0.28}\right)\left(\mathrm{PO}_{4}\right)_{2}$, are almost constant with $\mathrm{Mn} /(\mathrm{Mn}+\mathrm{Fe})$ ratios of 0.23 to 0.31 , i.e. almost the same as those of triphylite and ferrisicklerite. 

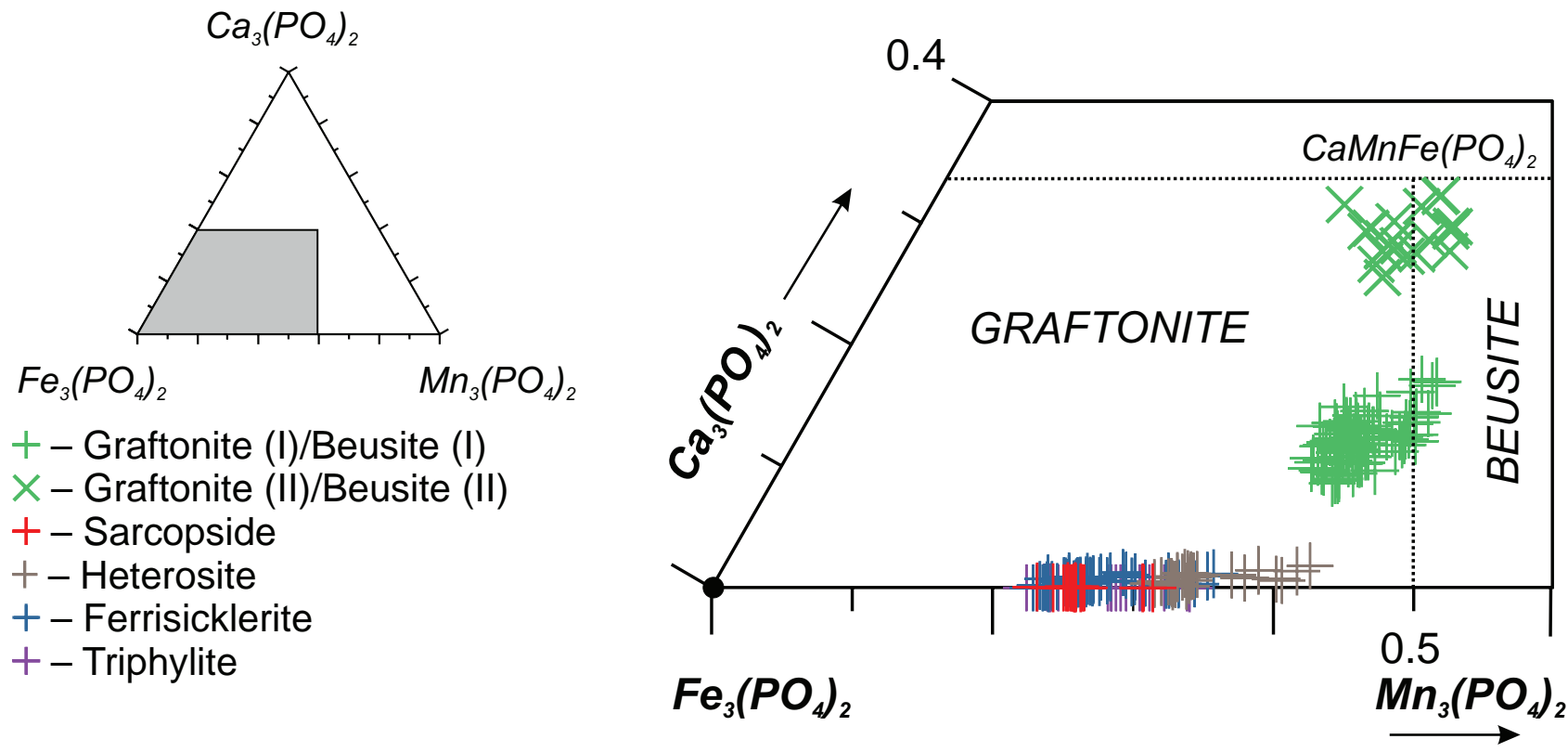

Fig. 7 Compositions of the primary phosphates from the lamellar intergrowths and metasomatic graftonite-(II)-beusite-(II) from veinlets in the ternary diagram $\mathrm{Fe}_{3}\left(\mathrm{PO}_{4}\right)_{2}-\mathrm{Ca}_{3}\left(\mathrm{PO}_{4}\right)_{2}-\mathrm{Mn}_{3}\left(\mathrm{PO}_{4}\right)_{2}$.

Graftonite, ferrisicklerite and sarcopside forming granular fillings in deformation zones are characterized by the same compositional parameters as their lamellar counterparts, proving that the granular texture is a result of cracking during consolidation of the pegmatite, maybe due to cooling (Tab. 3).

\subsubsection{The assemblage of metasomatic phosphates}

Graftonite-(II)-beusite-(II), regardless of its mode of occurrence, has distinctly lower $\mathrm{FeO}$ contents than the lamellar graftonite (16.24-24.31 vs. $24.32-31.32$ wt. \%,), higher $\mathrm{CaO}$ (12.48-15.75 vs. 4.07-8.12 wt. \%), slightly lower $\mathrm{MnO}$ (19.52-25.30 wt. \%), and $\mathrm{MgO}$ (0.08-0.73 wt. \%), and somewhat higher $\mathrm{ZnO}$ (up to 0.73 wt. \%) (Tab. 4). In terms of the Ca content the phase is comparable only with the Yellowknife Ca-rich beusite and the Räggen Ca-rich graftonite, and distinctly surpasses on that score Ca-rich graftonites-beusites from other localities (Wise and Černý 1990; Černý et al. 1998; Smeds et al. 1998). The compositions of the phosphates correspond to the formula $\left(\mathrm{Fe}^{2+}{ }_{0.86-1.11} \mathrm{Mn}_{0.94-1.21}\right.$ $\left.\mathrm{Ca}_{0.77-0.95} \mathrm{Mg}_{0.01-0.06} \mathrm{Zn}_{0.00-0.03}\right)\left(\mathrm{PO}_{4}\right)_{2}$, with $\mathrm{Mn} /(\mathrm{Mn}+\mathrm{Fe})$ ratios of $0.46-0.57$. The highest ratio has been noted in a relic grain surrounded by alluaudite and a jahnsitegroup mineral in the outer zone of a nodule (Fig. 5e). In the ternary diagram $\mathrm{Fe}_{3}\left(\mathrm{PO}_{4}\right)_{2}-\mathrm{Ca}_{3}\left(\mathrm{PO}_{4}\right)_{2}-\mathrm{Mn}_{3}\left(\mathrm{PO}_{4}\right)_{2}$ (Fig. 7), data points of graftonite-(II)-beusite-(II) cluster near the $\mathrm{CaMnFe}\left(\mathrm{PO}_{4}\right)_{2}$ composition, showing similar compositional trends and range of $\mathrm{Mn}-\mathrm{Fe}$ fractionation as the primary, lamellar graftonite-(I)-beusite-(I). This sug- gests that Ca-enrichment noted in the graftonite-beusite occurred at the expense of both $\mathrm{Fe}^{2+}$ and $\mathrm{Mn}^{2+}$ from the $M(1)$ site of the graftonite structure.

Minerals of the alluaudite group are strongly compositionally differentiated (Tab. 5). The $\mathrm{FeO}$ varies in the range 3.75-18.85 wt. \%, at $6.21-25.17$ wt. $\% \mathrm{Fe}_{2} \mathrm{O}_{3}$, $11.35-24.95$ wt. $\% \mathrm{MnO}, 0.44-4.41$ wt. \% $\mathrm{MgO}, 5.47-$ 9.28 wt. $\% \mathrm{Na}_{2} \mathrm{O}$, to 3.71 wt. $\% \mathrm{CaO}$ and to 0.13 wt. \% $\mathrm{K}_{2} \mathrm{O}$ (Tab. 5). Zinc and $\mathrm{Al}$ are always below detection. The $M(2)$-site may be dominated by either $\mathrm{Fe}^{2+}$ or $\mathrm{Fe}^{3+}\left(\mathrm{Fe}^{3+} /\right.$ $\mathrm{Fe}_{\text {total }}$ ratio ranges widely from 0.23 to 0.83 ) and so, according to the current nomenclature for the mineral group (Moore and Ito 1979; Hatert et al. 2006), the studied phases represent either hagendorfite or alluaudite. The $M(1)$ site is usually completely filled with $\mathrm{Mn}^{2+}$; only in several grains did $\mathrm{Fe}^{2+}$ exceed $\mathrm{Mn}^{2+}$, suggesting the presence of a ferrohagendorfite species. Calcium in the X(1) site never dominates, so $\mathrm{Na}$ and even $\mathrm{Mn}$ become important, whilst the $X(2)$ site is either dominated by $\mathrm{Na}$ or stays vacant. Li-bearing phosphates are replaced usually by hagendorfite of (MnNa) type, whilst fissures in the phosphates can already be filled with alluaudite of type (NaNa) or $(\mathrm{Na} \square)$. In symplectic intergrowths with wolfeite-staněkite occur commonly analogous alluaudites, although hagendorfite of type $(\mathrm{MnNa})$ and $(\mathrm{NaNa})$ may also be encountered. The $\mathrm{Mn} /(\mathrm{Mn}+\mathrm{Fe})$ ratio ranges widely $(0.26-0.56)$, being thus similar to the remaining phosphates of the metasomatic assemblage, covering the full range of the ratios in the primary triphylite, sarcopside and graftonite.

Minerals of the wagnerite group (wolfeite, triploidite and staněkite) have low $\mathrm{CaO}$ contents, up to 0.61 wt. \%, moderate $\mathrm{MgO}$, reaching 3.76 wt. $\%$, and $\mathrm{ZnO}$ up to 1.39 
Tab. 4 Representative compositions of metasomatic phosphates (except members of the alluaudite group) (wt. \% and apfu)

\begin{tabular}{|c|c|c|c|c|c|c|c|c|c|}
\hline & \multicolumn{2}{|c|}{ Graftonite-(II) Beusite-(II) } & \multirow{2}{*}{\multicolumn{2}{|c|}{ Wolfeite - Staněkite }} & \multirow{3}{*}{$\begin{array}{c}\text { Triploidite } \\
\text { LT13 }\end{array}$} & \multicolumn{2}{|c|}{ Kryzhanovskite } & \multirow[t]{2}{*}{ Phase A } & \multirow[t]{2}{*}{ Dickinsonite } \\
\hline & outer zone & veinlets & & & & & & & \\
\hline & L1 & LT4 & L1 & L1 & & L1 & L1 & LT11 & LT13 \\
\hline & 2 & 5 & 2 & 74 & 81 & 88 & 90 & 2 & 67 \\
\hline $\mathrm{P}_{2} \mathrm{O}_{5}$ & 41.44 & 41.97 & 32.19 & 32.41 & 31.94 & 35.13 & 35.50 & 45.54 & 40.66 \\
\hline $\mathrm{Al}_{2} \mathrm{O}_{3}$ & & & & & & & & & 2.13 \\
\hline $\mathrm{Fe}_{2} \mathrm{O}_{3}$ & & & & & & 2) 34.89 & 2) 30.97 & 1.65 & 0.42 \\
\hline $\mathrm{FeO}$ & 22.51 & 18.24 & 3) 47.27 & 3) 35.62 & 3) 30.54 & & & 2.57 & 20.09 \\
\hline $\mathrm{MnO}$ & 20.88 & 23.26 & 13.44 & 25.86 & 32.59 & 18.21 & 21.59 & 2.49 & 23.51 \\
\hline $\mathrm{MgO}$ & 0.32 & 0.55 & 1.98 & 1.65 & 0.40 & 1.37 & 1.58 & 1.11 & 1.35 \\
\hline $\mathrm{CaO}$ & 14.19 & 15.61 & 0.24 & 0.14 & 0.04 & 0.70 & 0.91 & 45.01 & 1.19 \\
\hline $\mathrm{SrO}$ & & & & & & & & & 0.27 \\
\hline $\mathrm{ZnO}$ & b.d.l. & 0.31 & 0.37 & 0.68 & b.d.l. & b.d.l. & b.d.l. & b.d.l. & b.d.l. \\
\hline $\mathrm{Na}_{2} \mathrm{O}$ & & & & & & & & 1.89 & 8.35 \\
\hline $\mathrm{K}_{2} \mathrm{O}$ & & & & & & & & & 1.31 \\
\hline $\mathrm{H}_{2} \mathrm{O}_{\text {(calc.) }}$ & & & 4.09 & 4.11 & 4.05 & 9.48 & 10.07 & & 1.19 \\
\hline Total & 99.35 & 99.93 & 99.57 & 100.46 & 99.57 & 99.78 & 100.62 & 100.25 & 100.48 \\
\hline \multicolumn{10}{|c|}{ Contents of ions ${ }^{1)}$} \\
\hline $\mathrm{P}^{5+}$ & 2.000 & 2.000 & 1.000 & 1.000 & 1.000 & 2.000 & 2.000 & 7.000 & 12.000 \\
\hline $\mathrm{Al}^{3+}$ & & & & & & & & & 0.876 \\
\hline $\mathrm{Fe}^{3+}$ & & & & & & 2) 1.765 & 2) 1.551 & & 0.124 \\
\hline $\mathrm{Fe}^{2+}$ & 1.073 & 0.858 & 3) 1.451 & 3) 1.086 & 3) 0.944 & & & ${ }^{3)} 0.616$ & 5.857 \\
\hline $\mathrm{Mn}^{2+}$ & 1.008 & 1.109 & 0.418 & 0.798 & 1.021 & 1.037 & 1.217 & 0.382 & 6.942 \\
\hline $\mathrm{Mg}^{2+}$ & 0.027 & 0.046 & 0.108 & 0.090 & 0.022 & 0.137 & 0.156 & 0.301 & 0.700 \\
\hline $\mathrm{Ca}^{2+}$ & 0.867 & 0.941 & 0.009 & 0.005 & 0.002 & 0.051 & 0.065 & 8.755 & 0.446 \\
\hline $\mathrm{Sr}^{2+}$ & & & & & & & & & 0.055 \\
\hline $\mathrm{Zn}^{2+}$ & 0.000 & 0.013 & 0.010 & 0.018 & 0.000 & 0.000 & 0.000 & 0.000 & 0.000 \\
\hline $\mathrm{Na}^{+}$ & & & & & & & & 0.666 & 5.641 \\
\hline $\mathrm{K}^{+}$ & & & & & & & & & 0.583 \\
\hline $\mathrm{O}^{2-}$ & 7.975 & 7.967 & 3.996 & 3.997 & 3.989 & 8.000 & 8.000 & 27.775 & 48.000 \\
\hline $\mathrm{OH}^{-}$ & & & 1.000 & 1.000 & 1.000 & 1.748 & 1.529 & 0.225 & 2.776 \\
\hline $\mathrm{H}_{2} \mathrm{O}_{\text {(calc.) }}$ & & & & & & 1.252 & 1.471 & & \\
\hline $\mathrm{Mn} /(\mathrm{Mn}+\mathrm{Fe})$ & 0.484 & 0.564 & 0.224 & 0.424 & 0.519 & 0.370 & 0.440 & 0.383 & 0.537 \\
\hline $\mathrm{Fe}^{3+} / \mathrm{Fe}_{\text {total }}$ & & & & & & & & 0.365 & 0.021 \\
\hline
\end{tabular}

$\mathrm{F}, \mathrm{Si}, \mathrm{Ti}, \mathrm{Ba}$ and $\mathrm{Pb}$ are below detection limit (b.d.l.); empty cell - component absent in the mineral

${ }^{1)}$ normalized to $1 \mathrm{P}$ apfu for wagnerite-group minerals, 2 P apfu for graftonite-(II)-beusite-(II) and kryzhanovskite, 7 P apfu for phase-A (a ferromerrillite-like mineral), and $12 \mathrm{P}$ apfu for dickinsonite

2) all $\mathrm{Fe}$ as $\mathrm{Fe}^{3+}$

3) all $\mathrm{Fe}$ as $\mathrm{Fe}^{2+}$

$\mathrm{H}_{2} \mathrm{O}$ and $\mathrm{Fe}^{3+} / \mathrm{Fe}_{\text {total }}$ ratios in phase- $A$ and a dickinsonite-like mineral are calculated by stoichiometry

wt. \%. These are higher than in other phosphates of the pegmatite (Tab. 4). Fluorine is always below detection under routine WDS analytical conditions $(\sim 0.10-0.15$ wt. \%), so species corresponding to triplite, $\left(\mathrm{Mn}, \mathrm{Fe}^{2+}\right)$ $\mathrm{PO}_{4}(\mathrm{~F}, \mathrm{OH})$, are absent. Iron and $\mathrm{Mn}$, two main substituents in the cation sites, are present at the levels 26.86-47.27 wt. \% FeO and 13.44-34.83 wt. \% $\mathrm{MnO}$ (0.841-1.450 Fe apfu and 0.418-1.105 Mn apfu). The $\mathrm{Mn} /(\mathrm{Mn}+\mathrm{Fe})$ ratio ranges from 0.22 to 0.57 , as in the coexisting alluaudite-group minerals. The wagneritegroup minerals with the $\mathrm{Mn} /(\mathrm{Mn}+\mathrm{Fe})>0.50$, i.e. corresponding to triploidite, are always connected with strongly altered lamellar graftonite-(I)-beusite-(I) [Mn/ $(\mathrm{Mn}+\mathrm{Fe}) \sim 0.50]$ and heterosite with this ratio varying from $0.31-0.35$ in inner, less metasomatized portions to
$0.37-0.42$ in the outer, more altered zones. $\mathrm{As} \mathrm{Fe}^{3+} / \mathrm{Fe}_{\text {total }}$ in the alluadites reaches a very high value of 0.83 , it is very likely that some of the wagnerite-group minerals attain the composition of staněkite.

Kryzhanovskite-(I) as a component of the granular metasomatic assemblage contains (in wt. \%) 30.52-34.89 $\mathrm{Fe}_{2} \mathrm{O}_{3}, 18.21-23.10 \mathrm{MnO}, 1.35-1.84 \mathrm{MgO}$ and $0.20-0.91$ $\mathrm{CaO}$ (Tab. 4). The composition corresponds to the formula $\left(\mathrm{Mn}_{1.04-1.33} \mathrm{Ca}_{0.01-0.06} \mathrm{Mg}_{0.14-0.19}\right)_{\Sigma=1.23-1.54} \mathrm{Fe}^{3+}{ }_{1.55-1.77}$ $\left(\mathrm{PO}_{4}\right)_{2}(\mathrm{OH})_{1.53-1.87} \cdot 1.13-1.47 \mathrm{H}_{2} \mathrm{O}$. The $\mathrm{Mn} /(\mathrm{Fe}+\mathrm{Mn})$ ratio of $0.37-0.46$ is similar to the co-existing members of the wagnerite and alluaudite groups. For instance, in neighboring crystals of the three minerals, the $\mathrm{Mn} /(\mathrm{Mn}+$ $\mathrm{Fe}$ ) ratios are 0.46 in alluaudite with staněkite and 0.45 in kryzhanovskite. 
A phosphate-bearing pegmatite from Lutomia, the Góry Sowie Block, Poland

Tab. 5 Representative compositions of the alluaudite-group minerals (wt. \% and apfu)

\begin{tabular}{|c|c|c|c|c|c|c|c|c|c|}
\hline & LT182 & L118 & LT47 & LT743 & LT31 & LT310 & L1111 & LT34 & L183 \\
\hline $\mathrm{P}_{2} \mathrm{O}_{5}$ & 43.61 & 43.98 & 43.65 & 42.91 & 44.26 & 43.96 & 43.00 & 42.74 & 43.19 \\
\hline $\mathrm{Fe}_{2} \mathrm{O}_{3}$ & 15.74 & 16.60 & 19.28 & 17.25 & 19.66 & 16.71 & 13.70 & 11.63 & 7.20 \\
\hline $\mathrm{FeO}$ & 10.04 & 9.79 & 7.62 & 10.18 & 12.69 & 15.42 & 18.85 & 15.57 & 15.21 \\
\hline $\mathrm{MnO}$ & 20.62 & 21.47 & 18.81 & 20.72 & 12.39 & 13.08 & 16.22 & 18.74 & 20.60 \\
\hline $\mathrm{MgO}$ & 3.53 & 2.74 & 1.01 & 0.44 & 3.99 & 4.11 & 1.91 & 1.81 & 4.04 \\
\hline $\mathrm{CaO}$ & 0.43 & 0.96 & 3.71 & 0.58 & 0.08 & 0.00 & 0.84 & 1.26 & 2.07 \\
\hline $\mathrm{Na}_{2} \mathrm{O}$ & 6.22 & 5.80 & 6.07 & 7.91 & 7.09 & 7.07 & 6.08 & 8.45 & 8.58 \\
\hline Total & 100.19 & 101.34 & 100.15 & 100.00 & 100.16 & 100.35 & 100.60 & 100.20 & 100.89 \\
\hline \multicolumn{10}{|c|}{ Contents of ions on the basis of $12 \mathrm{P}$ apfu } \\
\hline $\mathrm{P}^{5+}$ & 12.000 & 12.000 & 12.000 & 12.000 & 12.000 & 12.000 & 12.000 & 12.000 & 12.000 \\
\hline $\mathrm{Na}^{+}$ & 2.034 & 1.800 & 1.556 & 2.389 & 1.832 & 2.183 & 2.244 & 3.265 & 3.840 \\
\hline vacancy & 1.966 & 2.200 & 2.444 & 1.611 & 2.168 & 1.817 & 1.756 & 0.735 & 0.160 \\
\hline$\Sigma X(2)$ & 4.000 & 4.000 & 4.000 & 4.000 & 4.000 & 4.000 & 4.000 & 4.000 & 4.000 \\
\hline $\mathrm{Na}^{+}$ & 1.885 & 1.826 & 2.268 & 2.678 & 2.570 & 2.239 & 1.642 & 2.169 & 1.618 \\
\hline $\mathrm{Ca}^{2+}$ & 0.149 & 0.330 & 1.290 & 0.205 & 0.029 & 0.000 & 0.297 & 0.447 & 0.728 \\
\hline $\mathrm{Mn}^{2+}$ & 1.966 & 1.844 & 0.442 & 1.117 & 1.401 & 1.761 & 2.060 & 1.385 & 1.654 \\
\hline$\Sigma X(1)$ & 4.000 & 4.000 & 4.000 & 4.000 & 4.000 & 4.000 & 4.000 & 4.000 & 4.000 \\
\hline $\mathrm{Mn}^{2+}$ & 3.710 & 4.000 & 4.000 & 4.000 & 1.960 & 1.812 & 2.468 & 3.881 & 4.000 \\
\hline $\mathrm{Fe}^{2+}$ & 0.290 & 0.000 & 0.000 & 0.000 & 2.040 & 2.188 & 1.532 & 0.119 & 0.000 \\
\hline$\Sigma M(1)$ & 4.000 & 4.000 & 4.000 & 4.000 & 4.000 & 4.000 & 4.000 & 4.000 & 4.000 \\
\hline $\mathrm{Mn}^{2+}$ & 0.000 & 0.019 & 0.732 & 0.680 & 0.000 & 0.000 & 0.000 & 0.000 & 0.071 \\
\hline $\mathrm{Fe}^{2+}$ & 2.439 & 2.640 & 2.069 & 2.812 & 1.357 & 1.969 & 3.665 & 4.201 & 4.175 \\
\hline $\mathrm{Mg}^{2+}$ & 1.711 & 1.315 & 0.487 & 0.219 & 1.904 & 1.975 & 0.937 & 0.895 & 1.975 \\
\hline $\mathrm{Fe}^{3+}$ & 3.851 & 4.026 & 4.712 & 4.289 & 4.739 & 4.056 & 3.398 & 2.904 & 1.779 \\
\hline$\Sigma M(2)$ & 8.000 & 8.000 & 8.000 & 8.000 & 8.000 & 8.000 & 8.000 & 8.000 & 8.000 \\
\hline $\mathrm{Mn} /(\mathrm{Mn}+\mathrm{Fe})$ & 0.463 & 0.468 & 0.433 & 0.449 & 0.292 & 0.303 & 0.345 & 0.422 & 0.490 \\
\hline $\mathrm{Fe}^{3+} / \mathrm{Fe}_{\text {total }}$ & 0.585 & 0.604 & 0.695 & 0.604 & 0.582 & 0.494 & 0.395 & 0.402 & 0.299 \\
\hline
\end{tabular}

$\mathrm{Si}, \mathrm{Ti}, \mathrm{Al}, \mathrm{Zn}, \mathrm{Ba}, \mathrm{Pb}$ and $\mathrm{K}$ are below detection

$\mathrm{Fe}^{3+}$ was calculated by stoichiometry

Phase-A, close in composition to ferromerrillite, displays a clear variability in $\mathrm{CaO}(42.29-47.95$ wt. \%), $\mathrm{FeO}$ (3.23-4.56 wt. \%), $\mathrm{MnO}$ (1.06-4.56 wt. \%), MgO (0.64- 2.19 wt. \%) and $\mathrm{Na}_{2} \mathrm{O}(0.44-2.52$ wt. \%). The $\mathrm{Fe}^{3+} / \mathrm{Fe}_{\text {total }}$ ratio calculated for the anhydrous compositions ranges from 0.00 to 0.75 , and $\mathrm{Mn} /\left(\mathrm{Mn}+\mathrm{Fe}_{\text {total }}\right)$ from 0.25 to 0.54 (Tab. 4). The sum of cations, $10.53-10.95 \mathrm{pfu}$, is always higher than is typical of whitlockite, $\mathrm{Ca}_{9} \mathrm{Mg}(\mathrm{PO} 4)_{6}\left(\mathrm{PO}_{3} \mathrm{OH}\right)$. This, along with common prevalence $\mathrm{Fe}^{2+}$ over $\mathrm{Mg}^{2+}$, makes the compositions nearer to the end-member ferromerrillite, $\mathrm{Ca}_{9} \mathrm{FeNa}\left(\mathrm{PO}_{4}\right)_{7}$.

A dickinsonite-like mineral represents a $\mathrm{Mn}^{2+}$-dominant member in the arrojadite group (Cámara et al. 2006; Chopin et al. 2006). A relic of a mineral has high MnO contents prevailing over $\mathrm{FeO}$ ( 23.5 wt. $\%$ vs. $19.5-20.1$ wt. \%, respectively), low $\mathrm{Al}_{2} \mathrm{O}_{3}$ and $\mathrm{CaO}$, and very high $\mathrm{Na}_{2} \mathrm{O}$, reaching 8.35 wt. \% (Tab. 4). The mineral formula recalculated according to rules for the arrojadite group (Cámara et al. 2006; Chopin et al. 2006) is $\left(\mathrm{K}_{0.58-}\right.$ $\left.{ }_{0.62} \mathrm{Na}_{1.42-1.38}\right)_{\Sigma 2.00} \mathrm{Na}_{2.00}\left(\mathrm{Ca}_{0.45-0.68} \mathrm{Sr}_{0.05-0.10} \mathrm{Fe}^{2+}{ }_{0.22-0.50}\right)_{\Sigma 1.00}$ $\mathrm{Na}_{2.00}\left(\mathrm{Mn}_{6.85-6.94} \mathrm{Fe}^{2+}{ }_{5.36-5.40} \mathrm{Mg}_{0.70-0.75}\right)_{\Sigma 13.00}\left(\mathrm{Al}_{0.86-0.88}\right.$ $\left.\mathrm{Fe}^{3+}{ }_{0.12-0.14}\right)_{\Sigma 1.00}\left(\mathrm{PO}_{4}\right)_{11}\left[\mathrm{PO}_{3}(\mathrm{OH})_{0.78-0.92} \mathrm{Na}_{0.08-0.22}\right](\mathrm{OH})_{2}$, with a high $\mathrm{Mn} /(\mathrm{Mn}+\mathrm{Fe})$ of $\sim 0.54$, and a low $\mathrm{Fe}^{3+} / \mathrm{Fe}_{\text {total }}$ ratio of 0.02 .

Fluorapatite, normalized to $12 \mathrm{O}$ atoms and one $(\mathrm{F}, \mathrm{Cl}, \mathrm{OH})$ per formula unit, commonly displays an $\Sigma \mathrm{Me} / \mathrm{P}$ ratio exceeding the ideal value of $5: 3$, indicating a deficiency of $\left(\mathrm{PO}_{4}\right)^{3-}$, even when it is supplemented with traces of $\left(\mathrm{SiO}_{4}\right)^{4-}$ (to 1.80 wt. \% $\mathrm{SiO}_{2}$ ) and $\left(\mathrm{SO}_{4}\right)^{2-}$ (to 0.94 wt. \% $\left.\mathrm{SO}_{3}\right)$ (Tab. 6). It is a result of the $\left(\mathrm{CO}_{3}\right)^{2-}+(\mathrm{F} / \mathrm{OH})^{-}$ $\rightarrow\left(\mathrm{PO}_{4}\right)^{3-}$ substitution, identified in the infrared spectra of these apatites by a weak absorption band at c. 1430 $\mathrm{cm}^{-1}$. The calculated content of $\mathrm{CO}_{2}$ occasionally reaches 4.71 wt. \%, although it usually ranges from 1.5 to 2.5 wt. \%. Calcium deficiency is supplemented mainly with $\mathrm{Mn}$ (to $6.77 \mathrm{MnO}$ wt. \%) and $\mathrm{Fe}$ (to $5.88 \mathrm{FeO}$ wt. \%), and with traces of $\mathrm{ZnO}$ (to 0.42 wt. \%), $\mathrm{MgO}$ (to 0.47 wt. \%), $\mathrm{BaO}$ (to 0.37 wt. \%) and $\mathrm{Na}_{2} \mathrm{O}$ (to 0.40 wt. \%). The F content (2.17-4.30 wt. \%) is higher than $\mathrm{Cl}$ (to 0.80 wt. \%) and the calculated $\mathrm{H}_{2} \mathrm{O}$ amount (0.03-1.20 wt. \%). The $\mathrm{Mn} /(\mathrm{Mn}+\mathrm{Fe})$ ratio varies widely $(0.22-$ 0.94). The fluorapatite formula is: $\left(\mathrm{Ca}_{4.14-4.89} \mathrm{Mn}_{0.00-0.50}\right.$ $\left.\mathrm{Fe}_{0.00-0.43} \mathrm{Mg}_{0.00-0.06} \mathrm{Na}_{0.00-0.06} \mathrm{Zn}_{0.00-0.03} \mathrm{Ba}_{0.00-0.01}\right)_{\Sigma=5.00-5.05}$ $\left[\left(\mathrm{PO}_{4}\right)_{2.45-3.00}\left(\mathrm{SiO}_{4}\right)_{0.00-0.16}\left(\mathrm{SO}_{4}\right)_{0.00-0.06}\left(\mathrm{CO}_{3}\right)_{0.00-0.53}\right]_{\Sigma=3.00}$ $\left(\mathrm{F}_{0.57-1.15} \mathrm{OH}_{0.01-0.70} \mathrm{Cl}_{0.00-0.11}\right)_{\Sigma=1.00-1.53}$. 


\subsubsection{Secondary phosphates}

Ferrisicklerite and heterosite were chemically characterized, along with the primary lamellar triphylite, as products of topotactic oxidation connected with Li leaching (Sect. 5.2.1; Tab. 3). Representative compositions of other secondary phosphates produced by hydrothermal and weathering processes are presented in Tables 6 and 7 .

Phosphoferrite along with kryzhanovskite, replaced outward by ludlamite, are the most widespread secondary phosphates within the nodule interiors. Phosphoferrite displays diversified compositions with (in wt. \%) $\mathrm{FeO} 23.86-40.56, \mathrm{MnO} 10.52-22.12, \mathrm{CaO}<6.59$ and $\mathrm{MgO}<3.00$, supplemented by traces of $\mathrm{ZnO}$ (to 0.31 ), $\mathrm{Na}_{2} \mathrm{O}$ (to 0.24 ) and $\mathrm{K}_{2} \mathrm{O}$ (to 0.04$)$. The $\mathrm{Mn} /(\mathrm{Mn}+\mathrm{Fe}$ ) values of $0.21-0.46$ are inherited from the precursor lamellar graftonite-(I)-beusite-(I), triphylite and sarcopside. The phosphoferrite yields a formula $\left(\mathrm{Fe}^{2+}{ }_{1.34-2.34}\right.$ $\left.\mathrm{Mn}_{0.62-1.28} \mathrm{Ca}_{0.00-0.47} \mathrm{Mg}_{0.00-0.31} \mathrm{Zn}_{0.00-0.02} \mathrm{Na}_{0.00-0.03}\right)_{\Sigma=2.92-3.01}$ $\left(\mathrm{PO}_{4}\right)_{2} \cdot 3 \mathrm{H}_{2} \mathrm{O}$.
Kryzhanovskite-(II) varies in composition depending on the primary source mineral. That occurring as fillings in phosphoferrite or ludlamite fissures has $\mathrm{Mn} /(\mathrm{Mn}+\mathrm{Fe}) \mathrm{ra}-$ tios of 0.19-0.33, similar not only to those of the surrounding phosphoferrite, but also of triphylite and sarcopside of the primary, magmatic phosphate assemblage. It has high concentrations of $\mathrm{Fe}_{2} \mathrm{O}_{3}+\mathrm{FeO}$ (39.64-43.45 wt. \%), lower $\mathrm{MnO}$ (12.82-17.01 wt. \%), and very low concentrations of $\mathrm{CaO}$ (0.22-0.66 wt. \%), ZnO (0.27-0.44 wt. \%) and $\mathrm{MgO}$ (0.24-0.60 wt. \%) with negligible $\mathrm{Na}_{2} \mathrm{O}(0.05-0.08$ wt. \%). Its formula is $\left(\mathrm{Mn}_{0.73-0.95} \mathrm{Fe}^{2+}{ }_{0.00-0.21} \mathrm{Ca}_{0.02-0.05} \mathrm{Mg}_{0.02-0.06}\right.$ $\left.\mathrm{Zn}_{0.01-0.02} \mathrm{Na}_{0.01}\right)_{\Sigma=1.02-1.08} \mathrm{Fe}^{3+}{ }_{1.97-2.00}\left(\mathrm{PO}_{4}\right)_{2}(\mathrm{OH})_{2.01-2.17} \cdot 0.83-$ $0.99 \mathrm{H}_{2} \mathrm{O}$.

Kryzhanovskite-(II) occurring as separate grains at the contact with lamellar graftonite-(I) and also with phosphoferrite, i.e. as the graftonite alteration product, has higher $\mathrm{Mn} /(\mathrm{Fe}+\mathrm{Mn})$ of $0.38-0.47$, resembling those of the primary graftonite-(I). This krzyhanovskite has lower contents of $\mathrm{Fe}$, represented only by $\mathrm{Fe}_{2} \mathrm{O}_{3}$ (30.39-33.49 wt. \%), higher $\mathrm{MnO}$ (18.53-23.05 wt. \%), $\mathrm{CaO}(0.08-1.24$ wt. \%) and $\mathrm{MgO}(0.82-2.63$ wt. \%) with very low $\mathrm{ZnO}$ contents $(<0.19$ wt. \%). Its formula is $\left(\mathrm{Mn}_{1.05-1.32}\right.$ $\left.\mathrm{Mg}_{0.08-0.26} \mathrm{Ca}_{0.02-0.08}\right)_{\Sigma=1.33-1.49} \mathrm{Fe}^{3+}{ }_{1.55-1.69}$ $\left(\mathrm{PO}_{4}\right)_{2}(\mathrm{OH})_{1.61-1.76} \cdot 1.24-1.39 \mathrm{H}_{2} \mathrm{O}$.

Ludlamite is the first secondary mineral, whose $\mathrm{Mn} /(\mathrm{Mn}+\mathrm{Fe})$ of 0.01 to 0.48 document a Mn loss (the ratio typically attains higher values in the nodule center and decreases outwards). Ludlamite commonly contains (wt. \%) 22.80-46.79 FeO, 0.43-20.86 MnO, 0.15-4.48 $\mathrm{MgO}$, to $5.40 \mathrm{CaO}, 1.23 \mathrm{ZnO}$, and traces of $\mathrm{Na}_{2} \mathrm{O}$ (to 0.38 ) and $\mathrm{K}_{2} \mathrm{O}$ (to 0.39) (Tab. 6). The compositions yield a formula $\left(\mathrm{Fe}^{2+}{ }_{1.30-2.75} \mathrm{Mn}_{0.03-1.22}\right.$ $\mathrm{Ca}_{0.00-0.39} \mathrm{Mg}_{0.00-0.45} \mathrm{Zn}_{0.00-0.06} \mathrm{Na}_{0.00-0.05}$ $\left.\mathrm{K}_{0.00-0.03}\right)_{\Sigma=2.94-3.07}\left(\mathrm{PO}_{4}\right)_{2} \cdot 4 \mathrm{H}_{2} \mathrm{O}$.

Vivianite is a rare alteration product in the nodule rim, showing rather a low $\mathrm{Mn} /(\mathrm{Mn}+\mathrm{Fe})$ ratio of 0.05 to 0.25 . Mineral compositions (wt. \%), 16.86-31.79 FeO, 1.60-10.42 MnO, $0.24-0.87 \mathrm{MgO}$ and to $5.37 \mathrm{CaO}$ and $0.58 \mathrm{ZnO}$, supplemented by $\mathrm{Fe}_{2} \mathrm{O}_{3}$ (to 14.67 wt. \%), create a deficiency in the cation totals. The mineral formula is $\left(\mathrm{Fe}^{2+}{ }_{1.12-2.18} \mathrm{Mn}_{0.11-0.72} \mathrm{Fe}^{3+}{ }_{0.00-0.87}\right.$ $\left.\mathrm{Ca}_{0.00-0.46} \mathrm{Mg}_{0.00-0.10} \mathrm{Zn}_{0.00-0.04}\right)_{\Sigma=2.56-3.01}$ $\left(\mathrm{PO}_{4}\right)_{2} \cdot 8 \mathrm{H}_{2} \mathrm{O}$. Low $\mathrm{Mn} /(\mathrm{Mn}+\mathrm{Fe})$ ratios and a relatively high $\mathrm{Ca}$ contents found at some spots suggest 


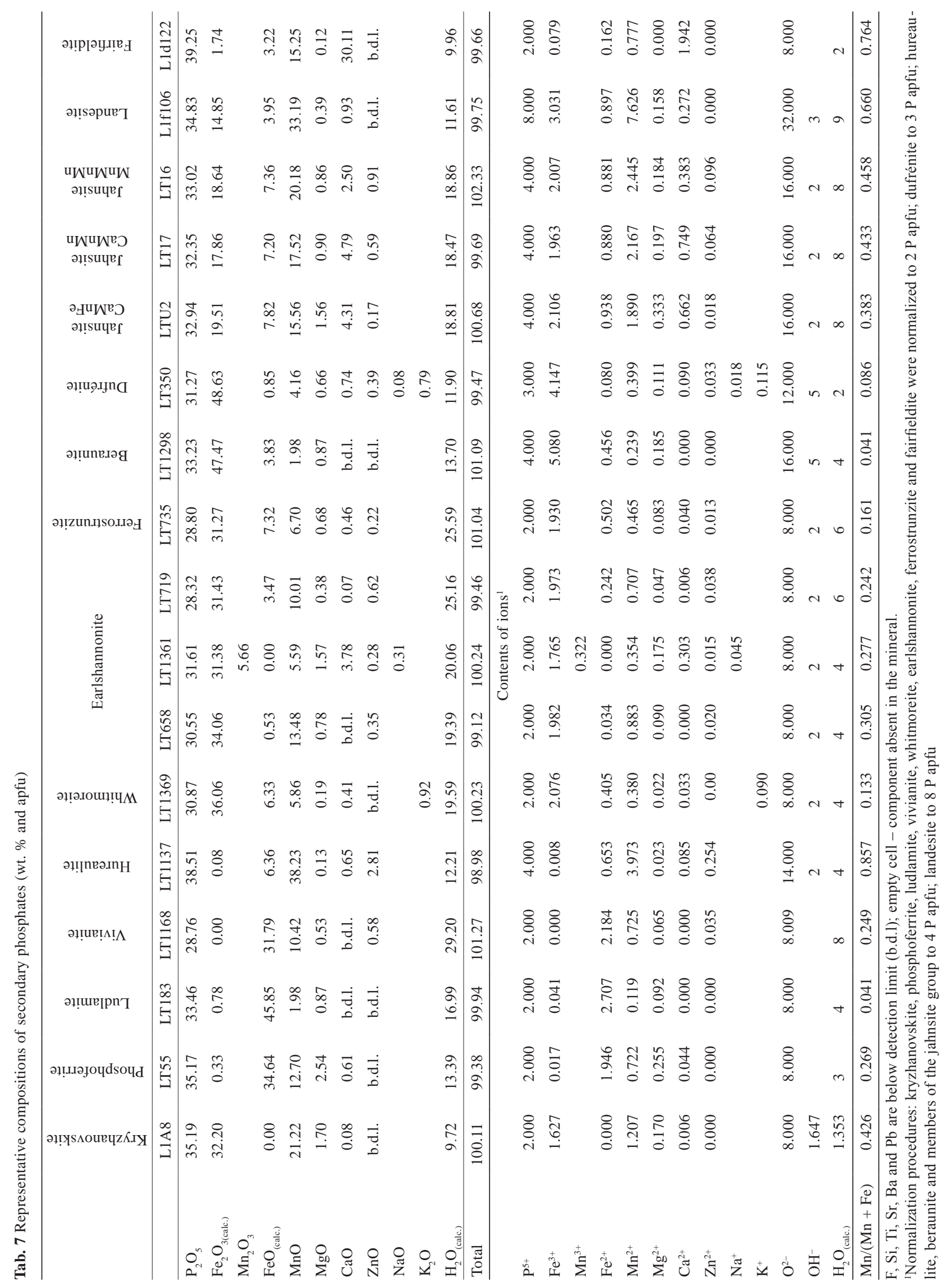


compositional affinity to both triphylite and sarcopside, as well as to graftonite.

Hureaulite has compositions close to that presented in Tab. 6, yielding a formula $\left(\mathrm{Mn}^{2+}{ }_{3.97-4.02} \mathrm{Fe}^{2+}{ }_{0.65-0.66} \mathrm{Zn}_{0.25-0.26}\right.$ $\left.\mathrm{Ca}_{0.04-0.08} \mathrm{Mg}_{0.02}\right)_{\Sigma=5}\left(\mathrm{PO}_{4}\right)_{4}(\mathrm{OH})_{2} \cdot 4 \mathrm{H}_{2} \mathrm{O}$, with $\mathrm{Mn} /(\mathrm{Mn}+$ $\mathrm{Fe}) \sim 0.86$.

The earlshannonite-whitmoreite series is commonly represented by earlshannonite, whereas whitmoreite is subordinate. Members of the series contain (in wt. \%) varying $\mathrm{Fe}_{2} \mathrm{O}_{3}$ and $\mathrm{FeO}, 25.44-39.35$ and $0.63-6.33$, respectively, 2.32-13.48 $\mathrm{MnO}, 0.18-2.74 \mathrm{MgO}$ and to 4.97 $\mathrm{CaO}$ and $0.79 \mathrm{ZnO}$. Occasionally they display up to 1.46 wt. \% $\mathrm{Na}_{2} \mathrm{O}$ and 1.54 wt. $\% \mathrm{~K}_{2} \mathrm{O}$ (Tab. 6). A deficiency in ferric iron $\left(\mathrm{Fe}_{\text {total }}<2 \mathrm{apfu}\right)$ can be supplemented with $\mathrm{Mn}_{2} \mathrm{O}_{3}$ reaching 12.34 wt. \%. The resulting formula is $\left(\mathrm{Mn}^{2+}{ }_{0.14-0.89} \mathrm{Fe}^{2+}{ }_{0.00-0.41} \mathrm{Ca}_{0.00-0.39} \mathrm{Mg}_{0.02-0.30} \mathrm{Zn}_{0.00-0.04} \mathrm{Na}_{0.00-0.21}\right.$ $\left.\mathrm{K}_{0.00-0.15}\right)_{\Sigma=0.74-1.09}\left(\mathrm{Fe}^{3+}{ }_{1.42-2.26} \mathrm{Mn}^{3+}{ }_{0.00-0.69}\right)\left(\mathrm{PO}_{4}\right)_{2}(\mathrm{OH})_{2}$. $4 \mathrm{H}_{2} \mathrm{O}$, with $\mathrm{Mn} /(\mathrm{Mn}+\mathrm{Fe})$ ratio ranging from 0.09 to 0.44 .

The strunzite-ferrostrunzite series is generally represented by strunzite; ferrostrunzite is found only occasionally. Members of the series contain (in wt. \%) 31.27-34.12 $\mathrm{Fe}_{2} \mathrm{O}_{3}, 0.24-7.32 \mathrm{FeO}$ and 4.77-13.06 MnO, with subordinate amounts of $\mathrm{MgO}(0.19-2.50), \mathrm{CaO}$ (to 1.07) and $\mathrm{ZnO}$ (to 0.87). The strunzite-ferrostrunzite formula is $\left(\mathrm{Mn}^{2+}{ }_{0.34-0.90} \mathrm{Fe}^{2+}{ }_{0.02-0.50} \mathrm{Ca}_{0.00-0.10} \mathrm{Mg}_{0.02-0.31}\right.$ $\left.\mathrm{Zn}_{0.00-0.05}\right)_{\Sigma=0.86-1.10} \mathrm{Fe}^{3+}{ }_{1.93-2.09}\left(\mathrm{PO}_{4}\right)_{2}(\mathrm{OH})_{2} \cdot 6 \mathrm{H}_{2} \mathrm{O} ; \mathrm{Mn} /(\mathrm{Mn}$ $+\mathrm{Fe}$ ) ratio ranges from 0.13 to 0.31 .

Dufrénite contains (wt. \%) 47.47-50.65 $\mathrm{Fe}_{2} \mathrm{O}_{3}, 0.73-$ 2.98 FeO and 2.76-6.98 $\mathrm{MnO}$, and traces of $\mathrm{CaO}$ (to 0.74 wt. \%), $\mathrm{MgO}(0.12-0.66$ wt. \%), $\mathrm{ZnO}$ (to 0.39 wt. \%), $\mathrm{K}_{2} \mathrm{O}$ (to 0.91 wt. \%) and $\mathrm{Na}_{2} \mathrm{O}$ (to 0.08 wt. \%), giving the formula $\left(\mathrm{Fe}^{2+}{ }_{0.07-0.28} \mathrm{Mn}^{2+}{ }_{0.26-0.66} \mathrm{Mg}_{0.02-0.11} \mathrm{Ca}_{0.00-0.09} \mathrm{Zn}_{0.00-0.03}\right.$ $\left.\mathrm{Na}_{0.00-0.02} \mathrm{~K}_{0.00-0.12}\right)_{\Sigma=0.61-1.00} \mathrm{Fe}^{3+}{ }_{4.00-4.29}\left(\mathrm{PO}_{4}\right)_{3}(\mathrm{OH})_{5} \cdot 2 \mathrm{H}_{2} \mathrm{O}$; $\mathrm{Mn} /(\mathrm{Mn}+\mathrm{Fe})$ ranges from 0.06 to 0.13 .

Beraunite found as tiny inclusions in dufrénite displays a rather constant composition, corresponding to the formula $\left(\mathrm{Fe}^{2+}{ }_{0.33-0.49} \mathrm{Mn}^{2+}{ }_{0.24-0.34} \mathrm{Mg}_{0.05-0.22} \mathrm{Ca}_{0.00-0.04} \mathrm{Zn}_{0.00-0.05}\right.$ $\left.\mathrm{K}_{0.00-0.10}\right)_{\Sigma=0.88-1.00} \mathrm{Fe}^{3+}{ }_{5.00-5.10}\left(\mathrm{PO}_{4}\right)_{4}(\mathrm{OH})_{5} \cdot 4 \mathrm{H}_{2} \mathrm{O}$; the $\mathrm{Mn} /$ $(\mathrm{Mn}+\mathrm{Fe})$ ratios are $\sim 0.04-0.06$.

Jahnsite-group minerals are represented mainly by jahnsite-(CaMnFe), more rarely by -(CaMnMn) and only occasionally by -(MnMnMn) varieties. In the minerals, the contents of several of the main components are highly variable $(\mathrm{FeO}=6.25-11.19$ wt. $\%, \mathrm{MnO}=11.76-20.18$ wt. $\%, \mathrm{CaO}=2.50-5.00$ wt. \%); however, $\mathrm{Fe}_{2} \mathrm{O}_{3}$ varies a little (18.03-19.51 wt. \%). $\mathrm{MgO}, \mathrm{ZnO}, \mathrm{Na}_{2} \mathrm{O}$ and $\mathrm{Al}_{2} \mathrm{O}_{3}$ occur only in traces $(0.86-2.19$ wt. \%, and up to $0.91,0.21$ and 0.40 wt. \%, respectively). The formula is $\left(\mathrm{Ca}_{0.38-0.78}\right.$ $\left.\mathrm{Mn}_{0.17-0.52} \mathrm{Zn}_{0.00-0.10} \mathrm{Na}_{0.00-0.06}\right)_{\Sigma=0.95-1.02}\left(\mathrm{Mn}_{0.89-1.00} \mathrm{Fe}^{3+}{ }_{0.00-0.11}\right)_{\Sigma=1.00}$ $\left(\mathrm{Fe}^{2+}{ }_{0.76-1.31} \mathrm{Mn}_{0.23-0.96} \mathrm{Mg}_{0.18-0.46}\right)_{\Sigma=2.00}\left(\mathrm{Fe}^{3+}{ }_{1.93-2.00} \mathrm{Al}_{0.00-0.07}\right)_{\Sigma=2.0}$ $\left(\mathrm{PO}_{4}\right)_{4}(\mathrm{OH})_{2} \cdot 8 \mathrm{H}_{2} \mathrm{O}$ with $\mathrm{Mn} /(\mathrm{Mn}+\mathrm{Fe})$ of $0.30-0.43$ in jahnsite-(CaMnFe), 0.42-0.43 in jahnsite-(CaMnMn) and 0.46 in jahnsite-(MnMnMn).
Landesite found in association with Mn-bearing hydroxyapatite and fairfieldite has a composition of $\left(\mathrm{Mn}^{2+}{ }_{7.63} \mathrm{Fe}^{2+}{ }_{0.90} \mathrm{Ca}_{0.27} \mathrm{Mg}_{0.16}\right)_{\Sigma=8.96} \mathrm{Fe}^{3+}{ }_{3.03}\left(\mathrm{PO}_{4}\right)_{8}(\mathrm{OH})_{3} \cdot 9 \mathrm{H}_{2} \mathrm{O}$; a high $\mathrm{Mn} /(\mathrm{Mn}+\mathrm{Fe})$ ratio equals to 0.66 (Tab. 6).

Fairfieldite is a relatively common in the outer zone of the alteration rim. It forms very homogeneous grains, containing (in wt. \%) $29.16-30.59 \mathrm{CaO}$, 13.67-16.79 $\mathrm{MnO}, 1.00-6.05 \mathrm{FeO}, 0.03-3.53 \mathrm{Fe}_{2} \mathrm{O}_{3}$ and traces of $\mathrm{MgO}$ (0.12-0.22), $\mathrm{ZnO}$ (to 0.20 ) and $\mathrm{Na}_{2} \mathrm{O}$ (to 0.14). The formula is $\left(\mathrm{Ca}_{1.89-1.96} \mathrm{Mn}_{0.71-0.87} \mathrm{Fe}^{2+}{ }_{0.05-0.31}\right.$ $\left.\mathrm{Fe}^{3+}{ }_{0.00-0.16} \mathrm{Mg}_{0.01-0.02} \mathrm{Zn}_{0.01} \mathrm{Na}_{0.02}\right)_{\Sigma=2.92-3.00}\left(\mathrm{PO}_{4}\right)_{3} \cdot 2 \mathrm{H}_{2} \mathrm{O}$ with $\mathrm{Mn} /(\mathrm{Mn}+\mathrm{Fe})=0.70-0.85$.

Hydroxyapatite displays lower $\mathrm{CO}_{2}$ contents than fluorapatite (to $2.27 \mathrm{wt}$ \%), and a mean at the level of 0.60 wt. \%, and $\mathrm{SiO}_{2}$ and $\mathrm{SO}_{3}$ attaining 0.20 wt. \% and 0.17 wt. \%, respectively. Calcium deficiency is supplemented mainly by $\mathrm{MnO}(0.46-11.88$ wt. \%), with traces of $\mathrm{FeO}$ (to 2.15 wt. \%), $\mathrm{ZnO}$ (to 0.26 wt. \%), SrO (to 0.32 wt. \%), $\mathrm{BaO}$ (to 0.13 wt. \%), $\mathrm{MgO}$ (to 0.03 wt. \%) and $\mathrm{Na}_{2} \mathrm{O}$ (to 0.40 wt. \%). The $\mathrm{OH}$ content exceeds that of $\mathrm{F}$ and $\mathrm{Cl}$ $\left(0.98-1.66 \mathrm{H}_{2} \mathrm{O}\right.$ wt. $\%$; to 1.47 wt. $\% \mathrm{~F}$ and 1.48 wt. $\left.\% \mathrm{Cl}\right)$. $\mathrm{The} \mathrm{Mn} /(\mathrm{Mn}+\mathrm{Fe})$ ratio, $0.81-1.00$, is higher than in fluorapatite. The hydroxyapatite formula is: $\left(\mathrm{Ca}_{4.00-4.96} \mathrm{Mn}_{0.03-0.87}\right.$ $\left.\mathrm{Fe}_{0.00-0.15} \mathrm{Na}_{0.00-0.07} \mathrm{Zn}_{0.00-0.02} \mathrm{Sr}_{0.00-0.02}\right)_{\Sigma=5.00-5.03}\left[\left(\mathrm{PO}_{4}\right)_{2.73-3.00}\right.$ $\left.\left(\mathrm{SiO}_{4}\right)_{0.00-0.02}\left(\mathrm{SO}_{4}\right)_{0.00-0.01}\left(\mathrm{CO}_{3}\right)_{0.00-0.27}\right]_{\Sigma=3.00}\left(\mathrm{OH}_{0.56-0.92} \mathrm{~F}_{0.00-0.38}\right.$ $\left.\mathrm{Cl}_{0.00-0.21}\right)_{\Sigma=1.00-1.27^{\circ}}$

\section{Associated minerals}

\subsection{Biotite}

A dark mica (biotite) is a relatively common component in the border and wall zones, where it forms medium-sized to large, dark-brown plates up to $3 \mathrm{~cm}$ across, without visible signs of alteration (Fig. 2a-b).

Tab. 8 Representative analysis of a dark mica

\begin{tabular}{lrl}
\hline & wt. \% & apfu \\
\hline $\mathrm{SiO}_{2}$ & 35.63 & 5.359 \\
$\mathrm{TiO}_{2}$ & 3.33 & 0.377 \\
$\mathrm{Al}_{2} \mathrm{O}_{3}$ & 19.92 & 3.531 \\
$\mathrm{~V}_{2} \mathrm{O}_{3}$ & 0.04 & 0.005 \\
$\mathrm{MnO}$ & 0.31 & 0.039 \\
$\mathrm{FeO}$ & 20.37 & 2.563 \\
$\mathrm{MgO}$ & 7.65 & 1.715 \\
$\mathrm{CaO}$ & 0.04 & 0.007 \\
$\mathrm{Na}$ & 0.19 & 0.055 \\
$\mathrm{~K}_{2} \mathrm{O}$ & 0.19 & 1.745 \\
$\mathrm{~F}$ & 9.11 & 0.056 \\
$\mathrm{H}_{2} \mathrm{O}_{\text {(calc.) }}$ & 0.12 & 3.944 \\
$-\mathrm{O}=\mathrm{F}_{2}$ & 3.93 & \\
\hline Total & -0.05 & \\
\hline
\end{tabular}

${ }^{1}$ normalized to $22 \mathrm{O}$ apfu; $\mathrm{H}_{2} \mathrm{O}$ calculated by stoichiometry 


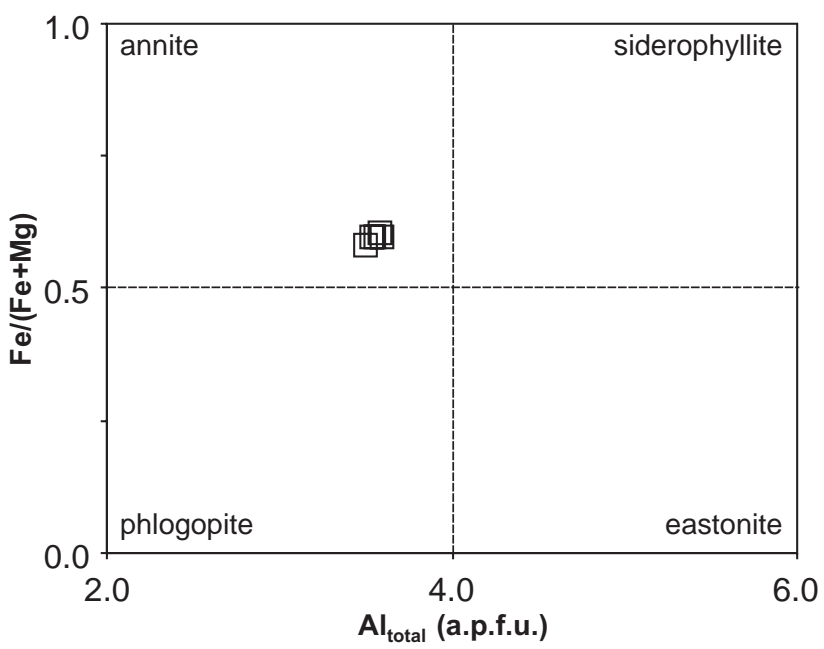

Fig. 8 Biotite classification in the $\mathrm{Al}_{\text {total }}$ vs. $\mathrm{Fe} /(\mathrm{Fe}+\mathrm{Mg})$ diagram.
$\mathrm{O}_{12}$, with rather low $\mathrm{Mn} /(\mathrm{Mn}+\mathrm{Fe})$ ratio of $\sim 0.30-0.31$ (Pieczka et al. 1997).

\subsection{Tourmaline}

Black tourmaline is a relatively rare mineral in the graphic intermediate and blocky feldspar zones. Crystals of the Lutomia tourmaline show similar features as that in the Piława Górna pegmatitic system (Pieczka et al. 2013). They are also composed basically of two distinct zones: a core, showing dark blue/blue $(\omega)$ to colorless $(\varepsilon)$ pleochroism, and a rim varying from olive-green $(\omega)$ to colorless $(\varepsilon)$. Representative analyses of the two varieties indicate comparable compositions, with $\mathrm{Ti}^{4+}$ as the only component that correlates with the observed differences in pleochroism (Tab. 9). The bluish core has very low $\mathrm{Ti}^{4+}$
Inwards, laths of biotite increase in size, reaching $10 \mathrm{~cm}$ in length in the graphic zone, where they sometimes occur with multigrain aggregates of muscovite commonly associated with tourmaline. In the blocky feldspar zone, isometric platy biotite with sizes to $10 \mathrm{~cm}$ forms intergrowths with K-feldspars. Biotite of both intermediate zones is commonly strongly chloritized. Titanite, ilmenite, fluorapatite and an allanite-group mineral form tiny inclusions in biotite of the border zone. Biotite compositions correspond to Mg- and Al-bearing annite (Tab. 8, Fig. 8). The average composition (in apfu), $5.36 \mathrm{Si}, 0.91$ ${ }^{\mathrm{VI}} \mathrm{Al}$ and $1.72 \mathrm{Mg}$, and moderate $\mathrm{Ti}$ (0.38), low $\mathrm{Mn}(\leq 0.04), \mathrm{Ca}(\leq 0.01)$ and $\mathrm{Na}(\leq 0.06)$, make the biotite closely comparable to that of the Piława pegmatitic system (Pieczka et al. 2013).

\subsection{Garnet}

Garnet is absent in the main pegmatite, but occurs in thin quartzbearing offshoots, a few centimeters thick, cutting the host amphibolite. It forms dodecahedral crystals up to $1.5-2.0 \mathrm{~cm}$ across, which have an almandine-spessartine composition, $\left(\mathrm{Fe}^{2+}{ }_{1.87} \mathrm{Mn}_{0.81} \mathrm{Mg}_{0.23} \mathrm{Ca}_{0.09}\right)_{\Sigma 3.00}$ $\left(\mathrm{Al}_{1.98} \mathrm{Fe}^{3+}{ }_{0.01} \mathrm{Ti}_{0.01}\right)_{\Sigma 2.00}\left(\mathrm{Si}_{2.95} \mathrm{Al}_{0.05}\right)_{\Sigma 3.00}$
Tab. 9 Representative compositions of tourmaline (wt. \% and apfu)

\begin{tabular}{|c|c|c|c|c|c|c|}
\hline & 6 & $\begin{array}{c}105 \\
\text { core }\end{array}$ & 128 & 7 & $\begin{array}{c}42 \\
\text { rim }\end{array}$ & 101 \\
\hline $\mathrm{SiO}_{2}$ & 36.60 & 36.24 & 36.42 & 36.16 & 36.17 & 35.95 \\
\hline $\mathrm{TiO}_{2}$ & 0.07 & 0.08 & b.d.l. & 0.16 & 0.28 & 0.21 \\
\hline $\mathrm{B}_{2} \mathrm{O}_{3 \text { (calc.) }}$ & 10.60 & 10.50 & 10.55 & 10.50 & 10.49 & 10.45 \\
\hline $\mathrm{Al}_{2} \mathrm{O}_{3}$ & 35.02 & 35.08 & 35.69 & 34.77 & 34.99 & 34.90 \\
\hline $\mathrm{Fe}_{2} \mathrm{O}_{3 \text { (calc.) }}$ & 0.78 & 0.00 & 0.00 & 0.00 & 0.00 & 0.00 \\
\hline $\mathrm{FeO}$ & 9.11 & 10.93 & 10.75 & 9.77 & 9.91 & 10.95 \\
\hline $\mathrm{MnO}$ & 0.17 & 0.13 & 0.08 & 0.13 & 0.14 & 0.06 \\
\hline $\mathrm{MgO}$ & 2.83 & 2.05 & 2.02 & 3.38 & 3.00 & 2.51 \\
\hline $\mathrm{CaO}$ & 0.03 & b.d.l. & b.d.l. & 0.06 & 0.06 & b.d.l. \\
\hline $\mathrm{Na}_{2} \mathrm{O}$ & 1.40 & 1.30 & 1.28 & 1.80 & 1.69 & 1.63 \\
\hline $\mathrm{K}_{2} \mathrm{O}$ & 0.03 & b.d.l. & b.d.l. & b.d.l. & 0.03 & 0.03 \\
\hline $\mathrm{H}_{2}^{2} \mathrm{O}_{\text {(calc.) }}$ & 3.66 & 3.56 & 3.48 & 3.26 & 3.19 & 3.26 \\
\hline Total & 100.26 & 99.87 & 100.28 & 99.99 & 99.95 & 99.95 \\
\hline \multicolumn{7}{|c|}{ Contents of ions ${ }^{1}$} \\
\hline $\mathrm{Na}^{+}$ & 0.445 & 0.416 & 0.409 & 0.577 & 0.545 & 0.524 \\
\hline $\mathrm{K}^{+}$ & 0.006 & 0.000 & 0.000 & 0.000 & 0.005 & 0.007 \\
\hline $\mathrm{Ca}^{2+}$ & 0.000 & 0.000 & 0.000 & 0.010 & 0.011 & 0.000 \\
\hline vacancy & 0.549 & 0.584 & 0.591 & 0.413 & 0.439 & 0.469 \\
\hline$\Sigma \mathrm{X}$ & 1.000 & 1.000 & 1.000 & 1.000 & 1.000 & 1.000 \\
\hline $\begin{array}{r}{ }_{\mathrm{Y}} \mathrm{Al}^{3+} \\
\end{array}$ & 0.766 & 0.845 & 0.929 & 0.774 & 0.831 & 0.820 \\
\hline${ }^{\mathrm{y}} \mathrm{Fe}^{3+}$ & 0.096 & 0.000 & 0.000 & 0.000 & 0.000 & 0.000 \\
\hline${ }^{\mathrm{Y}} \mathrm{Mn}^{2+}$ & 0.024 & 0.018 & 0.011 & 0.018 & 0.019 & 0.008 \\
\hline${ }^{\mathrm{y}} \mathrm{Fe}^{2+}$ & 1.248 & 1.514 & 1.481 & 1.354 & 1.374 & 1.523 \\
\hline${ }^{\mathrm{Y}} \mathrm{Mg}^{2+}$ & 0.691 & 0.507 & 0.496 & 0.835 & 0.741 & 0.622 \\
\hline${ }^{\mathrm{Y}} \mathrm{Ti}^{4+}$ & 0.009 & 0.010 & 0.000 & 0.020 & 0.035 & 0.026 \\
\hline$\Sigma \mathrm{Y}$ & 2.834 & 2.892 & 2.917 & 3.000 & 3.000 & 3.000 \\
\hline$\overline{{ }^{\mathrm{z}} \mathrm{Al}^{3+}}$ & 6.000 & 6.000 & 6.000 & 6.000 & 6.000 & 6.000 \\
\hline $\mathrm{B}^{3+}$ & 3.000 & 3.000 & 3.000 & 3.000 & 3.000 & 3.000 \\
\hline${ }^{\mathrm{T}} \mathrm{Si}^{4+}$ & 6.000 & 6.000 & 6.000 & 5.988 & 5.995 & 5.979 \\
\hline${ }^{\mathrm{T}} \mathrm{Al}^{3+}$ & 0.000 & 0.000 & 0.000 & 0.012 & 0.005 & 0.021 \\
\hline$\Sigma \mathrm{T}$ & 6.000 & 6.000 & 6.000 & 6.000 & 6.000 & 6.000 \\
\hline $\mathrm{O}^{2-}$ & 27.000 & 27.065 & 27.172 & 27.399 & 27.468 & 27.382 \\
\hline $\mathrm{OH}^{-}$ & 4.000 & 3.935 & 3.828 & 3.601 & 3.532 & 3.618 \\
\hline$M n /(M n+F e)$ & 0.017 & 0.012 & 0.007 & 0.013 & 0.014 & 0.005 \\
\hline $\mathrm{Fe} / \mathrm{Ti}$ & 152 & 158 & & 68 & 39 & 58 \\
\hline
\end{tabular}

${ }^{1}$ contents of ions on the basis of $\mathrm{Si}=6$ apfu for the core and $\mathrm{Y}+\mathrm{Z}+\mathrm{T}=15$ apfu for the rim tourmaline (see Methods)

F was always below detection limit (b.d.l.) 

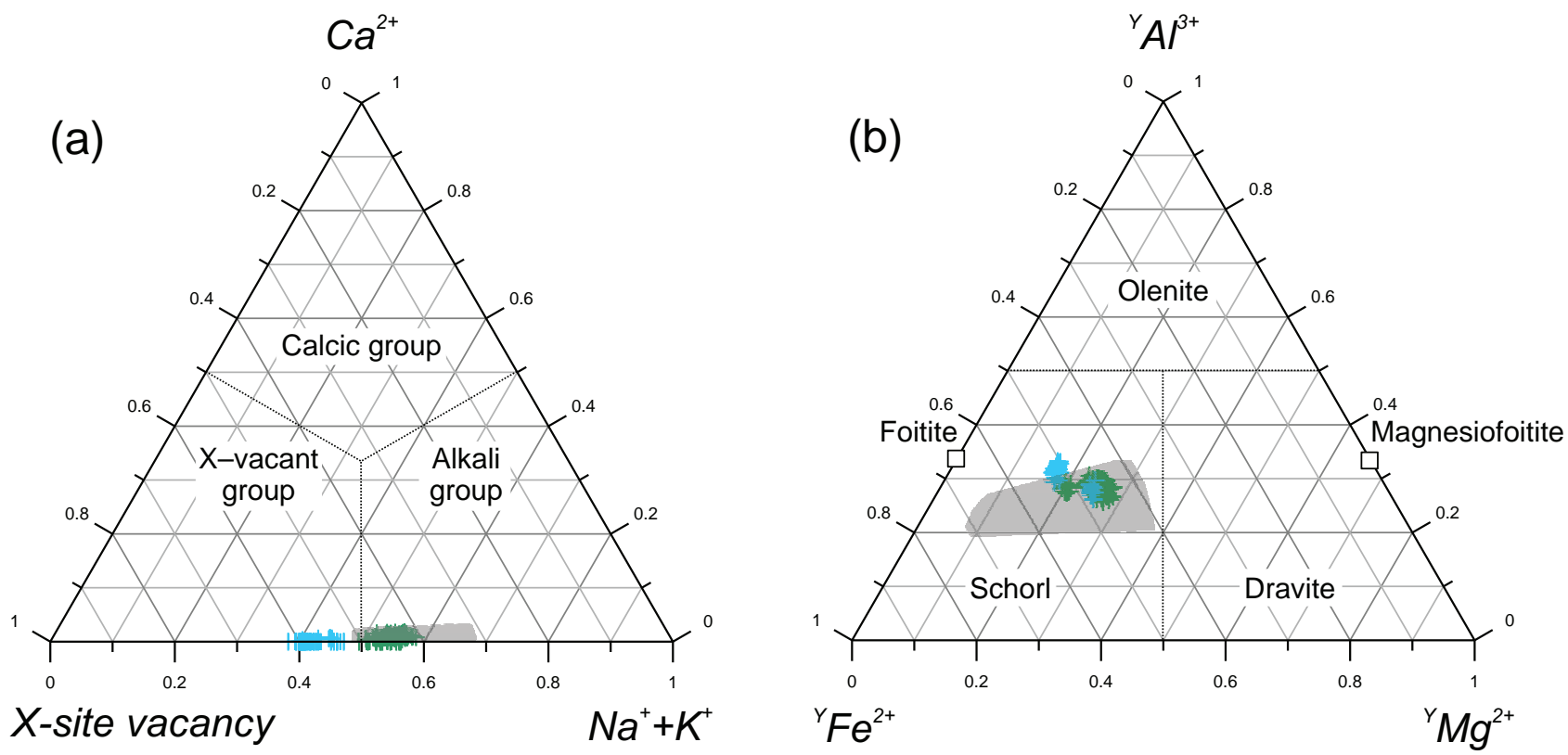

- core tourmaline

+ - mantle tourmaline

Fig. 9 Ternary plots of tourmaline compositions: $\mathbf{a}-\mathrm{X}$-site vacancy-Ca ${ }^{2+}-(\mathrm{Na}+\mathrm{K})^{+} ; \mathbf{b}-{ }^{\mathrm{Y}} \mathrm{Fe}-{ }^{\mathrm{Y}} \mathrm{Al}-{ }^{\mathrm{Y}} \mathrm{Mg}$. Grey fields denote compositions of the Piława Górna tourmalines (Pieczka et al. 2013).

contents, generally below 0.010 apfu, a very high Fe/Ti ratio varying from over 1000 to 100 , and $\mathrm{Mn} /(\mathrm{Mn}+\mathrm{Fe})$ ratio of $0.007-0.022$. In contrast, the rim tourmaline has $\mathrm{Ti}>0.018-0.019 \mathrm{apfu}$, distinctly lower $\mathrm{Fe} / \mathrm{Ti}(<80)$, and comparable $\mathrm{Mn} /(\mathrm{Mn}+\mathrm{Fe})$ ratio (0.005-0.021).

In the X-site vacancy-Ca- $(\mathrm{Na}+\mathrm{K})$ classification diagram (Fig. 9a), the core compositions represent $\mathrm{X}$-vacant tourmaline, whereas rims correspond to alkali tourmaline. In the ${ }^{\mathrm{Y}} \mathrm{Fe}_{\text {total }}-{ }^{\mathrm{Y}} \mathrm{Al}-{ }^{\mathrm{Y}} \mathrm{Mg}$ triangle (Fig. 9b), all the compositions plot in the center of the schorl field, close to the $\sim 30$ at. \% Al line of the $Y$ triad, corresponding approximately to the foitite-magnesiofoitite series. The relatively abundant $X$ site vacancies indicate the dominant role of the foitite within the core and schorl within the rim, supplemented in both cases by subordinate magnesiofoitite, dravite and olenite components. Simple compositional relationships link the black tourmaline to that from the Piława pegmatitic system (Pieczka et al. 2013) and the zoned tourmalines from pockets in common pegmatites of the Moldanubian Zone in Czech Republic (Gadas et al. 2012).

\subsection{Fergusonite- $(Y)$}

All compositions of the studied primary (Y,REE)(Nb,Ta,Ti) oxide fall in the fergusonite field of the CV1-CV2 three-group discrimination diagram of Ercit (2005) $(\mathrm{CV} 1=1.34$ to $1.81, \mathrm{CV} 2=-5.65$ to -6.34$)$. Thus they represent a species belonging to the fergusonite- or $\beta$-fergusonite group, distinguished by different symmetry,
I4 $/ a$ or I2, respectively. However, due to the presence of $\mathrm{U}^{4+}$ and $\mathrm{Th}^{4+}$, the minerals commonly are highly metamict and ambiguous recognition solely from EMP analyses is impossible. From necessity, the phase will be named fergusonite-(Y). In the Lutomia pegmatite, a mineral with such a composition occurs rarely as small $(<200 \mu \mathrm{m})$ inclusions, disseminated in perthite hosting some phosphate nodules. The contents of $\mathrm{Y}_{2} \mathrm{O}_{3}, H R E E_{2} \mathrm{O}_{3}$ and $L R E E_{2} \mathrm{O}_{3}$ are 21.56-24.30, 10.69-13.69 and 2.97-5.45 wt. \%, respectively, with $H R E E / R E E$ ratios varying from 0.69 to 0.77 (Tab. 10). The mineral also has relatively small $\mathrm{UO}_{2}$ and elevated $\mathrm{ThO}_{2}$ contents, 5.14-6.48 and 2.46-8.39 wt. \%, respectively, and $\mathrm{Th} /(\mathrm{Th}+\mathrm{U})$ ratio varies widely (0.28-0.60).

\section{Discussion}

\subsection{Origin of the pegmatite parental melt in a regional context}

The Lutomia pegmatite, dated to $370 \pm 4$ Ma (van Breemen et al. 1988), crystallized from a P-enriched granitelike magma coeval with 380-370 Ma metamorphic events in the GSB (van Breemen et al. 1988; Żelaźniewicz 1990; Bröcker et al. 1998; Timmermann et al. 2000; Aftalion and Bowes 2002; Gordon et al. 2005). Its sharp, discordant contacts with the host gneisses/amphibolites prove transport of the anatectic melt from deeper crustal levels. The parental magma was probably injected during the 
Tab. 10 Representative compositions of fergusonite-(Y) (wt. \% and apfu)

\begin{tabular}{|c|c|c|c|c|}
\hline & $\# 7$ & $\# 2 \mathrm{~N}$ & $\# 4 \mathrm{~N}$ & \#6N \\
\hline $\mathrm{WO}_{3}$ & 2.51 & 2.23 & 3.12 & 2.39 \\
\hline $\mathrm{Nb}_{2} \mathrm{O}_{5}$ & 38.21 & 36.02 & 38.07 & 37.28 \\
\hline $\mathrm{Ta}_{2} \mathrm{O}_{5}$ & 4.54 & 4.49 & 3.75 & 4.62 \\
\hline $\mathrm{SiO}_{2}$ & 0.30 & 0.32 & 0.85 & 0.16 \\
\hline $\mathrm{TiO}_{2}$ & 2.54 & 3.37 & 2.06 & 3.15 \\
\hline $\mathrm{ZrO}_{2}$ & 0.44 & 0.49 & 0.41 & 0.49 \\
\hline $\mathrm{ThO}_{2}$ & 2.46 & 8.39 & 7.06 & 5.24 \\
\hline $\mathrm{UO}_{2}$ & 6.40 & 5.83 & 5.14 & 6.48 \\
\hline $\mathrm{Sc}_{2} \mathrm{O}_{3}$ & b.d.l. & b.d.l. & 0.04 & 0.03 \\
\hline $\mathrm{Y}_{2} \mathrm{O}_{3}$ & 24.30 & 21.82 & 22.26 & 22.96 \\
\hline $\mathrm{La}_{2} \mathrm{O}_{3}$ & 0.08 & 0.10 & 0.10 & 0.10 \\
\hline $\mathrm{Ce}_{2} \mathrm{O}_{3}$ & 0.45 & 0.48 & 0.39 & 0.38 \\
\hline $\mathrm{Pr}_{2} \mathrm{O}_{3}$ & 0.11 & 0.04 & 0.14 & b.d.l. \\
\hline $\mathrm{Nd}_{2} \mathrm{O}_{3}$ & 0.90 & 1.47 & 1.56 & 1.43 \\
\hline $\mathrm{Sm}_{2} \mathrm{O}_{3}$ & 1.46 & 1.32 & 1.26 & 1.39 \\
\hline $\mathrm{Eu}_{2} \mathrm{O}_{3}$ & 0.72 & 0.79 & 0.77 & 0.89 \\
\hline $\mathrm{Gd}_{2} \mathrm{O}_{3}$ & 2.38 & 2.45 & 2.46 & 2.37 \\
\hline $\mathrm{Tb}_{2} \mathrm{O}_{3}$ & 0.59 & 0.39 & 0.41 & 0.55 \\
\hline $\mathrm{Dy}_{2} \mathrm{O}_{3}$ & 3.21 & 3.14 & 3.35 & 3.09 \\
\hline $\mathrm{Ho}_{2} \mathrm{O}_{3}$ & 0.85 & 0.74 & 0.84 & 0.80 \\
\hline $\mathrm{Er}_{2} \mathrm{O}_{3}$ & 2.83 & 2.67 & 2.49 & 2.59 \\
\hline $\mathrm{Tm}_{2} \mathrm{O}_{3}$ & 0.54 & 0.51 & 0.61 & 0.48 \\
\hline $\mathrm{Yb}_{2} \mathrm{O}_{3}$ & 2.34 & 2.05 & 2.16 & 2.00 \\
\hline $\mathrm{Lu}_{2} \mathrm{O}_{3}$ & 0.47 & 0.37 & 0.29 & 0.42 \\
\hline $\mathrm{CaO}$ & 0.48 & 0.42 & 0.70 & 0.39 \\
\hline Total & 99.14 & 99.90 & 100.27 & 99.68 \\
\hline \multicolumn{5}{|c|}{ Content of ions on the basis of $4 \mathrm{O}$ apfu } \\
\hline $\mathrm{Th}^{4+}$ & 0.026 & 0.091 & 0.077 & 0.056 \\
\hline $\mathrm{U}^{4+}$ & 0.067 & 0.062 & 0.055 & 0.068 \\
\hline $\mathrm{Sc}^{3+}$ & 0.000 & 0.000 & 0.002 & 0.001 \\
\hline $\mathrm{Y}^{3+}$ & 0.611 & 0.557 & 0.565 & 0.578 \\
\hline $\mathrm{La}^{3+}$ & 0.001 & 0.002 & 0.002 & 0.002 \\
\hline $\mathrm{Ce}^{3+}$ & 0.008 & 0.008 & 0.007 & 0.007 \\
\hline $\operatorname{Pr}^{3+}$ & 0.002 & 0.001 & 0.002 & 0.000 \\
\hline $\mathrm{Nd}^{3+}$ & 0.015 & 0.025 & 0.027 & 0.024 \\
\hline $\mathrm{Sm}^{3+}$ & 0.024 & 0.022 & 0.021 & 0.023 \\
\hline $\mathrm{Eu}^{3+}$ & 0.012 & 0.013 & 0.013 & 0.014 \\
\hline $\mathrm{Gd}^{3+}$ & 0.037 & 0.039 & 0.039 & 0.037 \\
\hline $\mathrm{Tb}^{3+}$ & 0.009 & 0.006 & 0.006 & 0.009 \\
\hline $\mathrm{Dy}^{3+}$ & 0.049 & 0.049 & 0.052 & 0.047 \\
\hline $\mathrm{Ho}^{3+}$ & 0.013 & 0.011 & 0.013 & 0.012 \\
\hline $\mathrm{Er}^{3+}$ & 0.042 & 0.040 & 0.037 & 0.038 \\
\hline $\mathrm{Tm}^{3+}$ & 0.008 & 0.008 & 0.009 & 0.007 \\
\hline $\mathrm{Yb}^{3+}$ & 0.034 & 0.030 & 0.031 & 0.029 \\
\hline $\mathrm{Lu}^{3+}$ & 0.007 & 0.005 & 0.004 & 0.006 \\
\hline $\mathrm{Ca}^{2+}$ & 0.024 & 0.022 & 0.036 & 0.020 \\
\hline$\Sigma A$ & 0.990 & 0.991 & 0.996 & 0.979 \\
\hline $\mathrm{W}^{6+}$ & 0.031 & 0.028 & 0.039 & 0.029 \\
\hline $\mathrm{Nb}^{5+}$ & 0.817 & 0.781 & 0.821 & 0.798 \\
\hline $\mathrm{Ta}^{5+}$ & 0.058 & 0.059 & 0.049 & 0.060 \\
\hline $\mathrm{Ti}^{4+}$ & 0.090 & 0.122 & 0.074 & 0.112 \\
\hline $\mathrm{Zr}^{4+}$ & 0.010 & 0.012 & 0.010 & 0.011 \\
\hline$\Sigma B$ & 1.006 & 1.000 & 0.992 & 1.010 \\
\hline$A+B$ & 1.996 & 1.991 & 1.988 & 1.990 \\
\hline $\mathrm{Ta} /(\mathrm{Ta}+\mathrm{Nb})$ & 0.067 & 0.070 & 0.056 & 0.069 \\
\hline
\end{tabular}

$\mathrm{Na}, \mathrm{K}, \mathrm{Mg}, \mathrm{Mn}, \mathrm{Fe}, \mathrm{Pb}, \mathrm{Al}$ and $\mathrm{Sn}$ are below detection limit (b.d.l.)
$\mathrm{D}_{4}$ decompression event, reflecting rapid exhumation of the GSB (Żelażniewicz 1990; Timmermann et al. 2000). It cannot be excluded that the lower crust was at a stage of advanced anatexis at that time (Żelaźniewicz 1990). However, rapid uplift of the GSB connected with decompression and fracture propagation should have prevented differentiation processes in the source. As widely accepted, volatile-rich residual melts with low viscosity can escape the parental granite to form pegmatite dikes within the country rocks. This mode of origin is assumed for a phosphate-bearing pegmatite in the Szklary serpentinite Massif (Sudetic ophiolite: Pieczka 2007). It is the only known representative of pegmatitic activity of $\sim 380 \mathrm{Ma}$ (CHIME Pb-U-Th dating on monazite; Pieczka unpublished data) in the GSB vicinity. This part of the Sudetic ophiolite (Majerowicz and Pin 1986) was in contact with the GSB in the Late Devonian times (Żelaźniewicz 1990).

\subsection{Classification of the Lutomia pegmatite}

Anatectic melting at the deeper levels of the GSB metasedimentary complex intercalated with lower crustal/ upper mantle lithologies (Gunia 1997; Kröner and Hegner 1998; Kryza and Fanning 2007; Ilnicki et al. 2012) could have produced a flux-bearing hybrid felsic magma (London 1992) enriched in incompatible, large-ion-lithophile and high-field-strength elements (HFSE), including $\mathrm{Li}^{+}$ and $\mathrm{P}^{5+}$. Such a magma, containing both crustally and mantle-derived components, could have been responsible for LCT- and NYF-type pegmatite formation (Martin and De Vito 2005; Simmons and Webber 2008). It could have been the case also for the GSB pegmatites, showing either the NYF evolving to an LCT, or only LCT, signatures. These form, as cogenetic and coeval bodies, one 'mixed' NYF + LCT system in the entire GSB region. Considering the geological-geochemical classification of the granitic pegmatites of Černý and Ercit (2005), the Lutomia pegmatite should be classified as the LCT berylcolumbite-phosphate subtype of the REL-Li subclass of rare-element pegmatites. However, such a classification is not a perfect match, due to the low abundance of $\mathrm{Nb}-\mathrm{Ta}$ oxides and the absence of beryl. These features point rather to the phosphate-subtype primitive pegmatites of the rare-element class in the modified classification of Novák (2005) applied to pegmatites of the Bohemian Massif. The presence of only scarce Be- and Nb-Ta mineralization, or even their absence, the relatively frequent primary Fe-Mn phosphates along with high B, and low F make such a link much more likely. Thus, in terms of the geochemical style of mineralization, the Lutomia pegmatite is close to classical Mn-Fe phosphates-bearing pegmatite localities in the Bohemian Massif such as Michałkowa in Poland (Websky 1868; Čech et al. 1962; Łodziński and Sitarz 2009), as well as Cyrilov (Staněk 
1955, 1971; Škoda et al. 2007) and Dolní Bory-Hatě (Stanĕk 1967, 1991, 2008) in the Czech Republic.

\subsection{Evolution of the Lutomia pegmatite}

The formation of phosphate nodules exhibiting lamellar texture with alternate graftonite and triphylite \pm sarcopside bands was a result of a complex process initiated probably by dissolution of a cooling parental P-bearing silicate melt into aluminosilicate and hydrosaline melts. This process was probably connected with separation of a fluid of lower salinity. For further discussion on melt and fluid inclusions in pegmatite-forming minerals, see Simmons and Webber (2008) based on data of Veksler and Thomas (2002), Thomas et al. (2006), and Thomas and Davidson (2013). Accepting this genetic model, the aluminosilicate content of the Lutomia pegmatite could have been related to the crystallization of the dominant aluminosilicate melt, whereas the formation of the phosphate nodules could be linked with crystallization of the separated, phosphate-bearing melt as a high-T Ca- and Li-enriched graftonite-like phase. The latter subsequently, upon cooling, broke down to graftonite, i.e. a structure preferring larger $\mathrm{Ca}^{2+}$ and $\mathrm{Mn}^{2+}$ cations, and a Ca- and Mn-poor, but Li-, Fe- and Mg-bearing, sarcopside-like phosphate, which further broke down into Li-bearing triphylite and Li-free sarcopside (Wise and Černý 1990; Černý et al. 1998; Smeds et al. 1998 and references therein; Vignola et al. 2008). The assemblage of the magmatic phosphates subsequently underwent metasomatic alteration of a high-T fluid released from the hydrosaline melt that followed the hydrothermal phase.

Cation partitioning between the exsolved minerals could have been driven by differences in the coordination of $\mathrm{Ca}^{2+}, \mathrm{Mg}^{2+}, \mathrm{Fe}^{2+}, \mathrm{Mn}^{2+}$ and $\mathrm{Li}^{+}$in the graftonite-beusite, sarcopside and triphylite structures. The preference of $\mathrm{Ca}^{2+}$ for the $M(1)$ site in graftonite was connected to change in coordination from 5-fold to 6-fold and even to 8-fold as the $M(1)$ cation changed from $\mathrm{Fe}^{2+}$ through $(\mathrm{Mn}, \mathrm{Fe})^{2+}$ to $\mathrm{Ca}^{2+}$ (Stelle et al. 1991). In consequence, the host graftonite-(I)-beusite-(I) and exsolved sarcopside + triphylite differ markedly in $\mathrm{Mn} /(\mathrm{Mn}+\mathrm{Fe})$ ratios (0.42-0.52 vs. $0.22-0.36$, respectively). The breakdown of the primary phosphate phase was induced by incompatible concentrations of $\mathrm{Ca}, \mathrm{Na}, \mathrm{Li}$ and $\mathrm{F}$ (at Lutomia mainly $\mathrm{Li}$ ) because the graftonite structure is stabilized in granitic pegmatites at moderate $\mathrm{Ca}$ and low F, Na and Li concentrations (Černý et al. 1998; Smeds et al. 1998). The $\mathrm{Mn} /(\mathrm{Mn}+\mathrm{Fe})$ ratio in the phosphates and associated garnet is commonly used to establish the degree of parental melt evolution (e.g. Černý et al. 1998; Smeds et al. 1998; Vignola et al. 2008). As shown above, in the Lutomia pegmatite the values are different for triphylite-sarcopside and graftonite, and apparently not com- patible with garnet. However, considering a proportion of 40-60 : 60-40 vol. \% between both types of lamellar phosphates, the resulting ratio of $0.36-0.37$ for the bulk phosphate composition is closer to that in garnet. It also should be remembered that garnet does not accompany the phosphates in the main pegmatite body, but occurs in peripheral offshoots cutting the amphibolite host. Therefore, as an earlier mineral, it may show slightly lower degree of Mn-Fe fractionation. These geochemical features allow us to classify the Lutomia pegmatite as a geochemically primitive, moderately fractionated body.

The primary lamellar assemblage underwent Ca- and Na-metasomatism connected with Fe oxidation (partly by an increase in $\mathrm{O}$ activity, and partly by $\mathrm{Li}^{+}$and $\mathrm{Na}^{+}$ leaching). It led to partial reconstruction of the magmatic phosphates with granular and granoblastic textures along micro-deformation fractures and in the outermost nodule zones, into a new assemblage composed of Carich graftonite/Ca-rich beusite + wolfeite/triploidite/ staněkite + hagendorfite/alluaudite + kryzhanovskite, and a Ca-bearing phosphate close to ferromerrillite finishing the crystallization. Graftonite-(I)-beusite-(I) and the metasomatic phosphates exhibit the similar Mn-Fe fractionation, expressed as $\mathrm{Mn} /(\mathrm{Mn}+\mathrm{Fe})$ ratios: $~ 0.52$ in graftonite-(I)-beusite-(I) versus 0.57 in beusite-(II) and wagnerite-group minerals, 0.56 in alluaudite-group minerals, and 0.54 in ferromerrillite-like minerals and an arrojadite-group mineral. This may indicate that the medium responsible for the formation of the metasomatic assemblage previously had evolved along with graftonite-(I) to separate finally in the form of a high$\mathrm{T}$ fluid enriched in $\mathrm{Na}$ and $\mathrm{F}$ but devoid of $\mathrm{Al}$. At the nodule/host plagioclase contact, fluorapatite continued crystallization as temperature decreased at increasing $\mathrm{Mn} /(\mathrm{Mn}+\mathrm{Fe})$ progressively to $\sim 0.90$ as a result from buffering of $\mathrm{F}$ activity by $\mathrm{Ca}^{2+}$ from the aluminosilicate melt crystallizing as the massive albite unit. This again indicates a decisive role for the fluids released by the hydrosaline melt. An influx of such a Na-enriched fluid destabilized phosphates of the primary assemblage stable only under low $\mathrm{F}$ and $\mathrm{Na}$ activities (Černý et al. 1998; Smeds et al. 1998), and liberated $\mathrm{Ca}^{2+}$ from the lamellar/ granular graftonite-(I)-beusite-(I) host, initiating Cametasomatism of the graftonite/beusite along the replacement front on the vein boundaries. Within the veinlets and outer zones, the primary phosphates were replaced by granular wolfeite/triploidite or staněkite depending on $\mathrm{Fe}$ : Mn relationships and Fe oxidation state, being surrounded by symplectites of the wagnerite- and alluauditegroup minerals, and in the axial parts of the veinlets by Ca- and Na-bearing phosphates close to ferromerrillite locally appearing along with hagendorfite. Alluaudite-group minerals of metasomatic origin, derived from triphylitegroup minerals by Na-for-Li exchange, are common in 
numerous pegmatites worldwide (Moore 1971; Huvelin et al. 1972; Fransolet 2007). Metasomatic wolfeite was described among others from the Otov I granitic pegmatite in western Bohemia (Masau et al. 2000), whilst staněkite, most often as an alteration product of ferrisicklerite, was recently mentioned from Cañada, Spain (Roda et al. 2004), Soè Valley, Italy (Guastoni et al. 2007) and Brissago, Switzerland (Vignola et al. 2008). In the Lutomia pegmatite, a genetic link of the secondary staněkite to the primary triphylite (or ferrisiscklerite as a product of topotactic oxidation) is also clearly visible. Staněkite forms anhedral grains embedded into ferrisicklerite and heterosite lamellae or occurs as small, regular chessboard mosaics in the ferrisicklerite-heterosite lamellae with dark brownish color in thin section. Alluaudite-group minerals and kryzhanovskite sometimes imitate the primary lamellar texture. Two contrasting tendencies are visible for both mineral groups: (1) grains with $\mathrm{Mn} /(\mathrm{Mn}+$ $\mathrm{Fe}$ ) ratio typical of the exsolved triphylite (ferrisicklerite) and sarcopside have slightly decreased $\mathrm{Mg}$ compared to the parental minerals $[\mathrm{Mg} /(\mathrm{Mg}+\mathrm{Mn}+\mathrm{Fe})=0.03-0.14$ in alluaudites and $0.03-0.10$ in the wagnerite-group minerals, versus $0.10-0.18$ in triphylite-ferrisicklerite and 0.05-0.09 in sarcopside]; (2) in grains with $\mathrm{Mn} /$ $(\mathrm{Mn}+\mathrm{Fe})$ ratio typical of the lamellar graftonite-(I), the $\mathrm{Mg} /(\mathrm{Mg}+\mathrm{Mn}+\mathrm{Fe})$ ratio increases from 0.02 to 0.15 in alluaudite-group minerals and from 0.01 to 0.07 in wagneritegroup minerals compared to $0.02-0.05$ in the host graftonite (Fig. 10). On the other hand, kryzhanovskite accompanying the assemblage [mainly the metasomatized graftonite-(II)beusite-(II)] displays this ratio varying in a very narrow range of 0.04-0.06. All the data suggest that metasomatism had reconstructed the entire granular assemblage, finally blurring the primary magmatic textures and compositional differences. The dickinsonite-like mineral found in the metasomatized outer zone of a single nodule probably represents the product of a reaction between the primary phosphates

Fig. 10 Ternary plot $\mathrm{Fe}_{3}\left(\mathrm{PO}_{4}\right)_{2}-$ $\mathrm{Mg}_{3}\left(\mathrm{PO}_{4}\right)_{2}-\mathrm{Mn}_{3}\left(\mathrm{PO}_{4}\right)_{2}$ for primary and metasomatic phosphates. and the parental fluid enriched in $\mathrm{Al}$ by interaction with the plagioclase host.

The appearance of an aqueous phase (and the later action of meteoric water) initiated hydrothermal alteration (hydration, auto-oxidation, oxidation and oxidation due to $\mathrm{Li}^{+}$- and $\mathrm{Na}^{+}$-leaching), initially preserving compositional relationships typical of the lamellar and metasomatic phosphates. This led to the formation of ferrisicklerite, stanékite and heterosite, possible transformation of hagendorfite into Na-poor alluaudite, formation of phosphoferrite, kryzhanovskite, jahnsite-group minerals and ludlamite, mainly in the nodule interior. Outwards, the minerals have been transformed into phosphate phases with elevated $\mathrm{Fe}^{3+}$, formed by partial to almost complete $\mathrm{Mn}^{2+}$ and $\mathrm{Ca}^{2+}$ removal (in a sequence of Mn-negligible ludlamite, vivianite, earlshannonite-whitmoreite, strunzite-ferrostrunzite, dufrénite, beraunite), predominating in the oxidation rim developed around the weakly altered nodule interior. The $\mathrm{Ca}^{2+}$ and $\mathrm{Mn}^{2+}$ ions liberated in the processes could have participated in crystallization of late $\mathrm{Ca}-\mathrm{Mn}-, \mathrm{Mn}-$ or Ca-bearing phases like hureaulite, landsite, fairfieldite and hydroxyapatite. The complex genesis of the secondary phosphates is best documented by the apatite-group minerals compositions analyzed in terms of the Mn-Fe fractionation vs. F contents in the crystal-

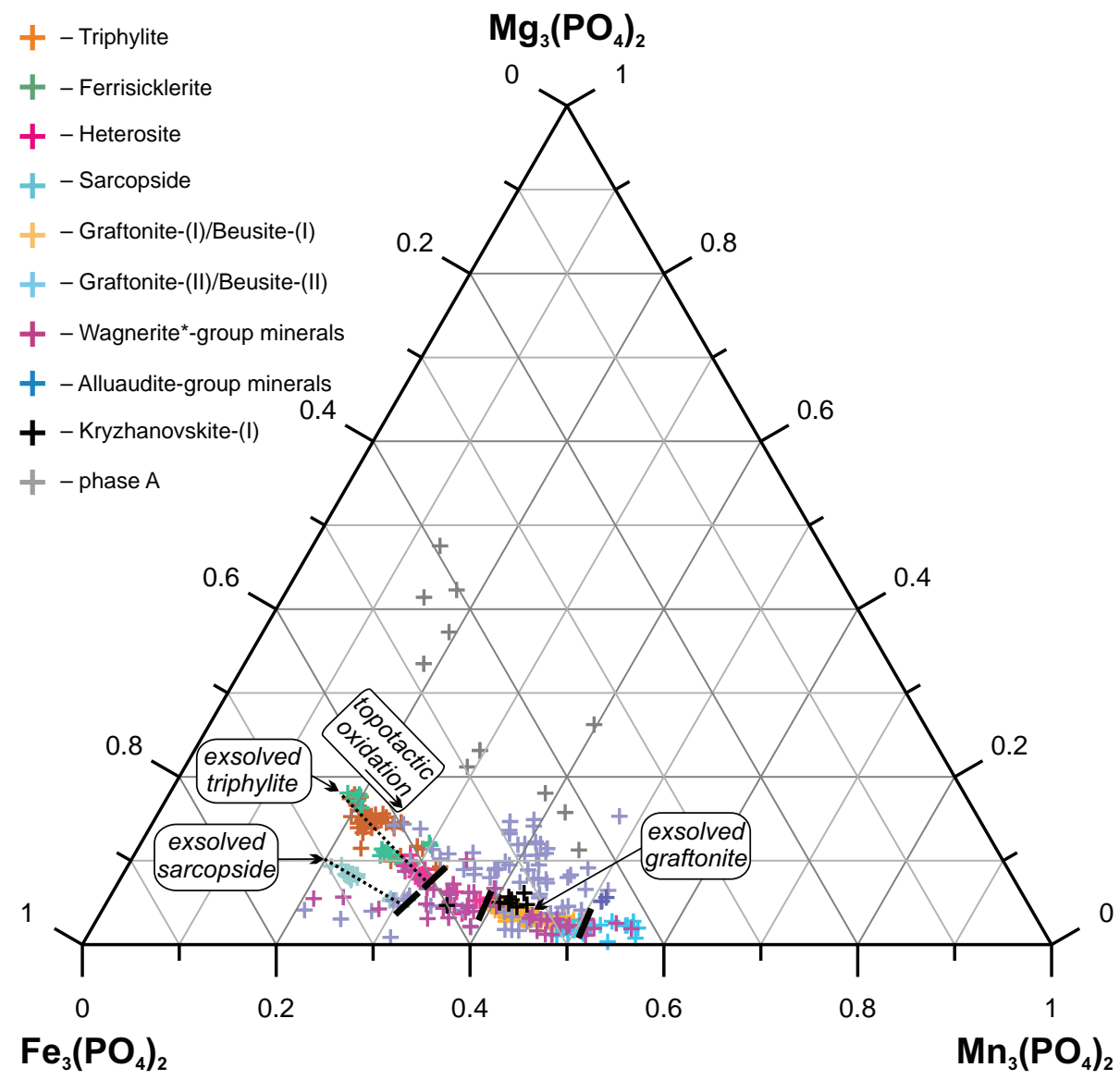


lization environment (Fig. 11). The plot clearly separates fluorapatite, with $\mathrm{Mn} /(\mathrm{Mn}+\mathrm{Fe})$ evolving progressively to $\sim 0.90$, from hydroxyapatite with distinctly lower $\mathrm{F}$ contents and with $\mathrm{Mn} /(\mathrm{Mn}+\mathrm{Fe})>0.90$. This corroborates two different media responsible for the formation of the secondary high- $\mathrm{T}$, metasomatic assemblage on the one hand and the secondary, hydrothermally-altered assemblage on the other.

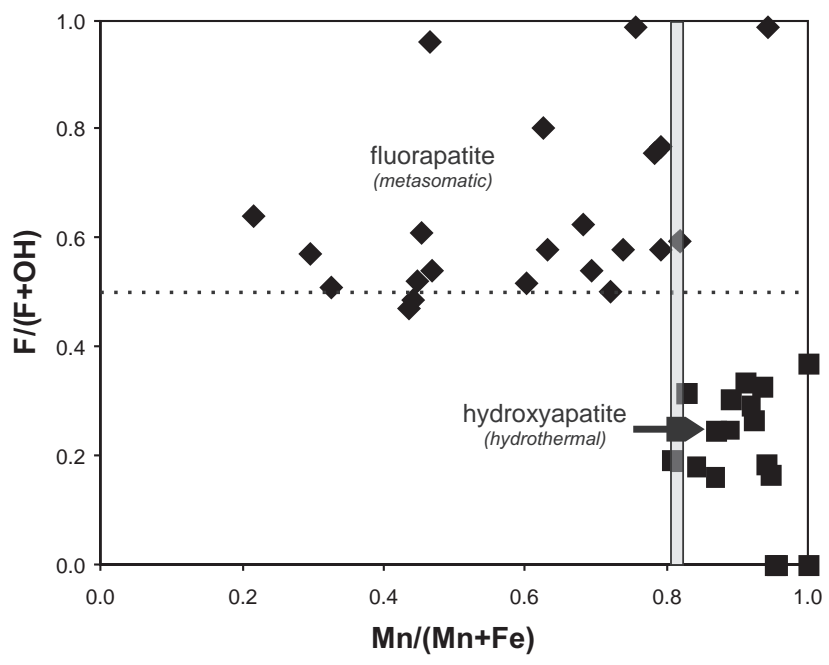

Fig. 11 Compositions of apatite-group minerals in $\mathrm{Mn} /(\mathrm{Mn}+\mathrm{Fe})$ vs. $\mathrm{F} /(\mathrm{F}+\mathrm{OH})$ plot.

\subsection{A relationship to the Michałkowa phosphate-bearing pegmatite}

The Michałkowa pegmatite was the first phosphatebearing pegmatite found in the GSB (Websky 1868), representing the type-locality for sarcopside. However, the pegmatite was only infrequently studied in the past, and data on its mineralogy are poor (see Čech et al. 1962; Łodziński and Sitarz 2009). The latter authors described now largely vanished material (currently available are only relics of a small dump, probably after Websky field work), and mentioned an occurrence of a dozen of phosphate minerals. However, besides graftonite and sarcopside, none of them was characterized in term of chemical composition, and their presence in the pegmatite is not convincing. From necessity, the brief description below of the phosphate-bearing mineralization at Michałkowa is made on the basis of the graftonite and sarcopside compositions published by Łodziński and Sitarz (2009) and our ongoing studies.

The pegmatite has the same origin and represents the same beryl-columbite-phosphate subtype of the $R E L-\mathrm{Li}$ subclass of rare-element pegmatites (Černý and Ercit 2005) or the phosphate subtype of the rare-element class (sensu Novák 2005). A columbite-group mineral (E. Szełęg, pers. comm.) and beryl (Łodziński 2007) are the only accessory components. Phosphate minerals can be found currently as nodules up to $5 \mathrm{~cm}$ in diameter (usually only 1-2 cm), mainly in blocky plagioclase. They commonly display three assemblages: (1) a primary one of lamellar or granular phosphates with graftonite, sarcopside and traces of triphylite oxidized topotacticly to ferrisicklerite and heterosite; (2) a metasomatic one, composed mainly of hagendorfite- and alluaudite-group minerals, wagnerite-group minerals (wolfeite and probably staněkite), arrojadite-group minerals, whitlockitegroup minerals, and (3) a hydrothermal to weathering vein-like and patchy phosphate assemblage, composed of jahnsite-group minerals, members of the kryzhanowskitephosphoferrite series, phosphosiderite, etc. The primary and metasomatic phosphates show lower Mn-Fe fractionation than those of Lutomia; in graftonite $\mathrm{Mn} /(\mathrm{Mn}+$ Fe) values are $0.34-0.46$, in sarcopside $0.12-0.24$, in tryphylite and ferrisicklerite $0.13-0.19$, in alluaudite-group minerals $0.19-0.45$ and in the wagnerite-group minerals 0.11-0.37. Metasomatism, more advanced than in the Lutomia pegmatite, commonly resulted in fine-grained textures, significantly blurring the primary lamellar one.

\subsection{A relationship to the Piława pegmatite system}

The active migmatite-amphibolite quarry at Piława Górna is the largest exposure of a complex suite of cogenetic rare-element pegmatites in the GSB. The system comprises differentiated pegmatites, ranging from homogeneous and relatively primitive dikes to simply zoned, NYF-affiliated bodies that may contain in central parts highly fractionated units of LCT mineralization with elbaite-liddicoatite-rossmanite tourmalines, lepidolite, spodumene, Cs-bearing micas and Cs-bearing beryl evolving to pezzottaite. The pegmatites are almost devoid of phosphate minerals, except for subordinate fluorapatite in the less fractionated NYF-like portion of the system, pale blue manganoan fluorapatite, relatively common in the most fractionated LCT facies, and an assemblage of accessory phosphates, including among others, lithiophyllite-purpurite, $\mathrm{LiMn}\left(\mathrm{PO}_{4}\right)-\mathrm{MnPO}_{4}$, and some other $\mathrm{Mn}-$ and $\mathrm{Mn}-\mathrm{Ca}$ phosphates with extremely high $\mathrm{Mn}-\mathrm{Fe}$ fractionation. They form only tiny grains accompanying Mn oxide inclusions around spodumene.

The differentiated pattern of the Piława Górna and Lutomia pegmatites is a result of the different behavior of $\mathrm{P}$ in the parental anatectic melt (see discussion in Roda et al. 2004). In both pegmatites, a source of P may be suspected in apatite-, monazite- and xenotime-type admixtures and organic matter existing in the primary sediments which underwent MP-HT metamorphism. According to Bea et al. (1992), apatite should be the first phosphate mineral crystallized from the peralumi- 
nous melt. However, at Lutomia (and Michałkowa), $\mathrm{P}^{5+}$ behaves differently, as characteristic of incompatible HFSE, accumulating in the primary melt. From this melt crystallized a high-T, Li-bearing graftonite-like phase, parental to numerous products of its breakdown, metasomatism and hydrothermal alteration. Such $\mathrm{P}$ behavior could possibly be related to early separation of aluminosilicate and phosphate-bearing melts and the co-crystallization of abundant plagioclase (oligoclasealbite), preventing apatite saturation in the aluminosilicate melt and buffering low Ca activity in the exsolved phosphate-bearing melt.

At Piława Górna, the existence of plagioclase is usually restricted to the border-, wall- and graphic intermediate zones, where it is gradually replaced by microcline; phosphorus precipitated here for a long time as a common fluorapatite. Other phosphates, e.g., lithiophyllite, were found only in very late LCT portions of the system with additional albitic and spodumene units (Szuszkiewicz et al. 2013); however, even here they were preceded by crystallization of relatively abundant Mn-bearing fluorapatite. Both systems, i.e. Lutomia/Michałkowa and Piława Górna, also experienced a stage with increasing $\mathrm{Fe}^{3+}$ activity and late $\mathrm{Ca}$ metasomatism. At Piława Górna these phenomena were related, among others, to stages of $(\mathrm{Fe}, \mathrm{Mn})-(\mathrm{Ti}, \mathrm{Sn})-(\mathrm{Nb}, \mathrm{Ta})-$ and $(\mathrm{Y}, \mathrm{REE}, \mathrm{U}, \mathrm{Fe})-(\mathrm{Ti}, \mathrm{Sn})-$ (Nb,Ta) oxide formation and their later hydrothermal alteration (Pieczka et al. 2013, 2014), whilst at Lutomia and Michakowa their results were observed in the metasomatic and hydrothermal and weathering phosphates.

\section{Conclusions}

The Lutomia pegmatite from the Góry Sowie Block (GSB) in Lower Silesia, Poland, represents a fine example of the relatively moderately-fractionated phosphate subtype of geochemically primitive LCT pegmatites of the rare-element class. It contains three phosphate assemblages of different origin. The primary assemblage comprises lamellar intergrowths of graftonite evolving to beusite with exsolved triphylite and sarcopside, destroyed in micro-deformation zones, and with tiny inclusions of monazite- $(\mathrm{Ce})$ and rare xenotime-(Y). The assemblage was subjected to $\mathrm{Na}$ - and $\mathrm{Ca}$-metasomatism induced by a high-T fluid separated from a P-bearing hydrosaline melt. As consequence, the primary graftonite-beusite, triphylite and sarcopside were transformed to secondary Ca-bearing graftonite-beusite, and hagendorfite- and alluaudite-group minerals, wolfeite, triploidite and staněkite, kryzhanovskite, a merrillite-like mineral, a dickinsonitelike mineral and fluorapatite crystallized at the contacts with the host albite. The action of hydrothermal solutions and meteoric water marked the transformation of the magmatic and metasomatic phosphates into a new assemblage composed of ferrisicklerite and heterosite formed by topotactic oxidation of triphylite, phosphoferrite, kryzhanovskite, ludlamite, vivianite, earlshannonite-whitmoreite, strunzite-ferrostrunzite, jahnsite-group minerals, dufrénite and beraunite. All these phases show increasing hydration and $\mathrm{Fe}^{3+}$ contents, especially in an outer alteration rim. Liberation of $\mathrm{Ca}^{2+}$ and $\mathrm{Mn}^{2+}$ at final stages of these transformations resulted in crystallization of late hureaulite, landesite, earlshannonite and Mn-bearing hydroxyapatite. The increased Mn-Fe fractionation corroborates differentiated $\mathrm{Fe}$ and $\mathrm{Mn}$ behavior at late stages of the pegmatite evolution. The pegmatite, coeval with the $\sim 380-370$ Ma metamorphic event in the GSB, formed from an anatectic, P-enriched granite-like magma, mobilized and injected during the $\mathrm{D}_{4}$ decompression related to the rapid exhumation of the GSB.

Acknowledgements. The authors would like to thank Radek Škoda, Pietro Vignola and Milan Novák (handling editor) for their helpful reviews and comments. The work was financially supported by AGH University of Science and Technology grant 10.10.140.319.

Electronic supplementary material. The detailed account of analytical techniques used is available online at the Journal web site (http://dx.doi.org/10.3190/jgeosci.185).

\section{References}

Aftalion M, Bowes DR (2002) U-Pb zircon isotopic evidence for Mid-Devonian migmatite formation in the Góry Sowie domain of the Bohemian Massif, Sudeten Mountains, SW Poland. Neu Jb Mineral, Mh 4: 182-192

Bea F, Fershater G, Corretgé LG (1992) The geochemistry of phosphorus in granite rocks and the effect of aluminium. Lithos 29: 43-56

Bröcker M, ŻELAźNIEWICZ A, Enders M (1998) Rb-Sr and $\mathrm{U}-\mathrm{Pb}$ geochronology of migmatitic gneisses from the Góry Sowie (West Sudetes, Poland): the importance of Mid-Late Devonian metamorphism. J Geol 155: 1025-1036

Brueckner HK, Blusztajn J, BaKun-Czubarow N (1996) Trace element and Sm-Nd "age" zoning in garnets from peridotites of the Caledonian and Variscan mountains and tectonic implications. J Metamorph Geol 14: 61-73

Cámara F, Oberti R, Chopin C, Medenbach O (2006) The arrojadite enigma: I. A new formula and a new model for the arrojadite structure. Amer Miner 91: 1249-1259

Čech F, Paděra K, Povondra P (1962) The sarcopside problem. Acta Univ Carol, Geol 3: 145-157

ČERnÝ P, ERCIT TS (2005) The classification of granitic pegmatites revisited. Canad Mineral 43: 2005-2026 
Černý P, Selway JB, Ercit TS, Anderson AJ, Anderson SD (1998) Graftonite-beusite in granitic pegmatites of the Superior Province: a study in contrast. Canad Mineral 36: 367-376

Chopin C, Oberti R, Cámara F (2006) The arrojadite enigma: II. Compositional space, new members and nomenclature of the group. Amer Miner 91: 1260-1270

ERCIT TS (2005) Identification and alteration trends of granitic-pegmatite-hosted (Y,REE,U,Th)-(Nb,Ta,Ti) oxide minerals: a statistical approach. Canad Mineral 43: 1291-1303

FiedLer H (1863) Die Mineralien Schlesiens mit Berücksichtigung der angrenzenden Länder. F. E. C. Leuckart, Breslau, pp 1-100

Fransolet AM (2007) Phosphate associations in the granitic pegmatites: the relevant significance of these accessory minerals. In: Martins T, Vieira R (eds) Granitic Pegmatites: the State of Art - International Symposium, 6-12 $2^{\text {th }}$ May, Porto, Portugal. Universidade do Porto, Departemento de Geologia, Memorias 8: 102-103

Gadas P, Novák M, Staněk J, Filip J, Vašinová Galiová M (2012) Compositional evolution of zoned tourmaline crystals from pockets in common pegmatites of the Moldanubian Zone, Czech Republic. Canad Mineral 50: 895-912

Gordon SM, Schneider DA, Manecki M, Holm DK (2005) Exhumation and metamorphism of an ultrahigh-grade terrane: geochronometric investigations of the Sudetes Mountains (Bohemia), Poland and Czech Republic. J Geol Soc, London 162: 841-855

Grocholski W (1967) Structure of the Sowie Mts. Geol Sudetica 3: 181-249 (in Polish, English summary)

Guastoni A, Nestola F, Mazzoleni G, Vignola P (2007) Mn-rich graftonite, ferrisicklerite, staněkite and Mn-rich vivianite in a granitic pegmatite at Soè Valley, central Alps, Italy. Mineral Mag 71: 579-585

Gunia P (1997) Petrology of ultrabasic rocks from the Góry Sowie Block. Prace Geol Miner 65: 1-78 (in Polish, English summary)

Gunia T (1985) Geological position of the Sowie Góry Block and its influence on the paleogeography of the Paleozoic of Central Sudetes. Geol Sudetica 20: 83-119 (in Polish, English summary)

Hatert F, Fransolet AM, Maresh W (2006) The stability of primary alluaudites in granitic pegmatites: an experimental investigation of the $\mathrm{Na}_{2}\left(\mathrm{Mn}_{2-2 \mathrm{x}} \mathrm{Fe}_{1+2 \mathrm{x}}\right)\left(\mathrm{PO}_{4}\right)_{3}$ system. Contrib Mineral Petrol 152: 399-419

Huvelin P, Orliac M, Permingeat F (1972) Ferri-alluaudite calcifére de Sidi-bou-Othmane (Jebilet, Maroc). Notes Serv Géol Maroc 32-241: 35-49

Ilnicki S, Nejbert K, Pieczka A, Szelęg E, Turniak K, Szuszkiewicz A, Łodziński M, Banach M, Michąowski P, RóżNIAK R (2010) Eclogites from the Piława Górna quarry (Dolnośląskie Surowce Skalne S.A.), Góry Sowie Block, SW Poland: a preliminary report. Miner Spec Papers 37: 81

Ilnicki S, Nejbert K, Pieczka A, Szelęg E, Turniak K, Szuszkiewicz A, Łodziński M, Banach M, MichaŁowski P, RóżNiAK R (2011) Metamorphic record of retrogressed eclogites from the Piława Górna (Sowie Góry Block, SW Poland). Miner Spec Papers 38: 103-104

Ilnicki S, Nejbert K, Pieczka A, Szelęg E, Turniak K, SzuszKIEwicz A (2012) Geochemical and petrological features of eclogites from Piława Górna (Góry Sowie Block, SW Poland). Miner Spec Papers 40: 78-79

Keller F, Fontan F, Velasco-Roland F, Melgarejo I, DRAPER JC (1997) Staněkite $\mathrm{Fe}^{3+}\left(\mathrm{Mn}, \mathrm{Fe}^{2+}, \mathrm{Mg}\right)\left(\mathrm{PO}_{4}\right) \mathrm{O}$ : a new phosphate mineral in pegmatites at Karibib (Namibia) and French Pyrénées (France). Eur J Mineral 9: 475-482

KRÖNER A, Hegner E (1998) Geochemistry, single zircon ages and $\mathrm{Sm}-\mathrm{Nd}$ systematics of granitoid rocks from the Góry Sowie (Owl Mts.), Polish West Sudetes: evidence for early Palaeozoic arc-related plutonism. J Geol Soc, London 155: 711-724

KRYZA R (1981) Migmatization in gneisses of the northern part of the Sowie Góry, Sudetes. Geol Sudetica 16: 7-91 (in Polish, English summary)

Kryza R, Fanning CM (2007) Devonian deep-crustal metamorphism and exhumation in the Variscan Orogen: evidence from SHRIMP zircon ages from the HT-HP granulites and migmatites of the Góry Sowie (Polish Sudetes). Geodin Acta 20: 159-176

LoNDON D (1992) The application of experimental petrology to the genesis and crystallization of granitic pegmatites. Canad Mineral 30: 499-540

ŁodzińsKi M (2007) Mineralogical study of beryls from Polish and Czech Sudetes. Prace Mineral, PAN Kraków 93: 5-179 (in Polish, English summary)

Łodziński M, Sitarz (2009) Chemical and spectroscopic characterization of some phosphate accessory minerals from pegmatites of the Sowie Góry Mts, SW Poland. J Mol Struct 924-926: 442-447

Majerowicz A, Pin C (1986) Preliminary trace element evidence for an oceanic depleted mantle origin of the Ślęża ophiolitic complex, SW Poland. Mineral Pol 17: 12-22.

Martin RF, De Vito C (2005) The patterns of enrichment in felsic pegmatites ultimately deepend on tectonic setting. Canad Mineral 43: 2027-2048

Masau M, Staněk J, Černý P, Chapman R (2000) Metasomatic wolfeite and associated phosphates from the Otov I granitic pegmatite, western Bohemia. J Czech Geol Soc 45: $159-173$

Mason B (1941) Minerals of the Varaträsk pegmatite. XXIII. Some iron-manganese phosphate minerals and their alteration products, with special reference to material from Varaträsk. Geol Fören Förh 63: 117-175 
Moore PB (1971) Crystal chemistry of the alluaudite structure type: contribution to the paragenesis of pegmatite phosphate giant crystals. Amer Miner 54: 1955-1975

Moore PB (1974) Complete mixed valence solid solution series in $\mathrm{Fe}^{2+}{ }_{3}\left(\mathrm{H}_{2} \mathrm{O}\right)_{3}\left(\mathrm{PO}_{4}\right)_{2}$ (phosphoferrite) $\mathrm{Fe}_{3}^{3+}(\mathrm{OH})_{3}\left(\mathrm{PO}_{4}\right)_{2}$ (kryzhanovskite). Nature 251: 305-306

Moore PB, Araki T (1976) Mixed-valence solidsolution series. Crystal structures of phosphoferrite, $\mathrm{Fe}^{2+}{ }_{3}\left(\mathrm{H}_{2} \mathrm{O}\right)_{3}\left[\mathrm{PO}_{4}\right]_{2}$, and kryzhanovskite, $\mathrm{Fe}_{3}^{3+}(\mathrm{OH})_{3}\left[\mathrm{PO}_{4}\right]_{2}$. Inorg Chem 15: 316-321

Moore PB, Iто J (1979) Alluaudites, wyllieites, arrojadites: crystal chemistry and nomenclature. Mineral Mag 43: 227-235

Moore PB, Araki T, Kampf A R (1980) Nomenclature of the phosphoferrite structure type: refinements of landesite and kryzhanovskite. Mineral Mag 43: 789-795

Morawski T (1973) The Sowie Góry area and its petrological problems. In: SMulikowski K (ed) Revue des Problèms Géologiques des Zones Profondes de l'Ecorce Terrestre en Basse Silesie. Wydawnictwa Geologiczne, Warszawa, pp 44-58

NovÁk M (2005) Granitic pegmatites of the Bohemian Massif (Czech Republic); mineralogical, geochemical and regional classification and geological significance. Acta Mus Moraviae, Sci Geol 90: 3-75 (in Czech, English summary)

O’Brien PJ, Kröner A, JAeckel P, Hegner E, ŻELAŹNIEWicZ A, KrYZA R (1997) Petrological and isotope studies on Palaeozoic high-pressure granulites. Góry Sowie Mts, Polish Sudetes. J Petrol 38: 433-456

PIECZKA A (2007) Beusite and unusual Mn-rich apatite from the Szklary granitic pegmatite, Lower Silesia, Poland. Canad Mineral 45: 901-914

Pieczka A, GoŁębiowska B, Kraczka J (1997) Mn-garnets from the Sowie Mts metamorphic pegmatites. Mineral Pol 28: 81-88

Pieczka A, GoŁęBiowska B, Skowroński A (2003) Ferrisicklerite and other phosphate minerals from the Lutomia pegmatite (SW Poland, Lower Silesia, Góry Sowie Mts). In: CempíreK J (ed) International Symposium on Light Elements in Rock-Forming Minerals, Nové Město na Moravě, Czech Republic, June 20-25, 2003, Book of Abstracts. Masaryk University \& Moravian Museum, Brno, pp 63-64

Pieczka A, Łobos K, Sachanbiński M (2004) The first occurrence of elbaite in Poland. Mineral Pol 35: 3-14

Pieczka A, Szuszkiewicz A, SzeŁęg E, Nejbert K, Łodziński M, Ilnicki S, Turniak K, Banach M, Holub W, Michałowski P, Różniak R (2013) (Fe,Mn)-(Ti,Sn)(Nb,Ta) oxide assemblage in a little fractionated portion of a mixed (NYF + LCT) pegmatite from Piława Górna, the Sowie Mts. Block, SW Poland. J Geosci 58: 91-112

Pieczka A, Szuszkiewicz A, SzeŁęg E, Ilnicki S, Nejbert K, TurNiAK K (2014) Samarskite-group minerals and alteration products: an example from the Julianna pegmatitic system, Piława Górna, SW Poland. Canad Mineral 52: 303-319

Polański A (1955) On the metamorphism of crystalline formations of the Sowie Mts (Middle Sudeten). Arch Mineral 18: 211-284 (in Polish, English summary)

Quensel P (1937) Minerals of the Varuträsk pegmatite. I. The lithium-manganese phosphates. Geol Fören Förh 62: 297-302

Roda E, Pesquera A, Fontan F, Keller P (2004) Phosphate minerals associations in the Cañada pegmatite (Salamanca, Spain): paragenetic relationships, chemical compositions, and implications for pegmatite evolutions. Amer Miner 89: 110-125

Simmons WB, Webber K (2008) Pegmatite genesis: state of art. Eur J Mineral 20: 421-438

ŠKoda R, StaněK J, Čopjaková R (2007) Mineral assemblages of the phosphate nodules from the granitic pegmatite at Cyrilov near Velké Meziřríčí, Moldanubicum; part 1 - primary and exsolution phases. Acta Mus Moraviae, Sci Geol 92: 59-74 (in Czech, English summary)

Smeds SA, Uher P, Černý P, Wise MA, Gustafsson L, Penner P (1998) Graftonite-beusite in Sweden: primary phases, products of exsolution, and distribution in zoned populations of granitic pegmatites. Canad Mineral 36: 377-394

STANĚK J (1955) On paragenesis of phosphates from Cyrilov near Vel. Meziříčí. Čas Morav Muz (Brno) 40: 69-80 (in Czech)

STANĚK J (1967) Trifylite, sarkopside and alluaudite from pegmatite near Dolní Bory on western Moravia. Čas Morav Muz (Brno) 52: 35-42 (in Czech, English summary)

STANĚK J (1971) Study of secondary phosphates of iron and manganese from pegmatite at Cyrilov. Folia Fac Sci Nat Univ Purk Brun 22: 25-48 (in Czech, English summary)

STANĚK J (1991) Paragenesis of minerals from pegmatite dikes at Hatě near Dolní Bory on western Moravia. Acta Mus Moraviae, Sci Nat 76: 19-49 (in Czech, English summary)

StANĚK J (2008) Die Mineralien aus den Pegmatitgängen von Dolní Bory-Hatě, Tschechische Republik. Aufschluss 59: 81-102 (in German)

Stelle IM, Olsen E, Pluth J, Davis AM (1991) Occurrence and crystal structure of Ca-free beusite in the El Sampal IIIA iron meteorite. Amer Miner 76: 1985-1989

Szuszkiewicz A, Szęęg E, Pieczka A, Ilnicki S, Nejbert K, Turniak K, Banach M, Łodziński M, RóżNiaK R, MichaŁowsKi P (2013) The Julianna pegmatite vein system at the Piława Górna mine, Góry Sowie Block, SW Poland - preliminary data on geology and descriptive mineralogy. Geol Q 57: 467-484

Tait KT, Hawthorne FC, Wise MA (2013) The crystal chemistry of the graftonite-beusite minerals. Canad Mineral 51: 653-662

Thomas R, Davidson P (2013) The missing link between granites and granitic pegmatites. J Geosci 58: 183-200 
Thomas R, Webster JD, Davidson P (2006) Understanding pegmatite formation: the melt and fluid inclusion approach. In: Webster JD (ed) Melt Inclusions in Plutonic Rocks. Mineralogical Association of Canada Short Courses 36: 189-210

Timmermann H, Parrish RR, Noble SR, Kryza R (2000) New U-Pb monazite and zircon data from the Sudetes Mountains in SW Poland; evidence for a single-cycle Variscan Orogeny. J Geol Soc, London 157: 265-268

van Breemen O, Bowes DR, Aftalion M, Żelaźniewicz A (1988) Devonian tectonothermal activity in the Sowie Góry gneissic Block, Sudetes, southwestern Poland: evidence from $\mathrm{Rb}-\mathrm{Sr}$ and $\mathrm{U}-\mathrm{Pb}$ isotopic studies. Ann Soc Geol Pol 58: 3-10

VeKsler IV, Thomas R (2002) An experimental study of B-, $\mathrm{P}$ - and F-rich synthetic granite pegmatite at 0.1 and 0.2 GPa. Contrib Mineral Petrol 143: 673-683
Vignola P, Diella V, Oppizzi P, Tiepolo M, Weiss S (2008) Phosphate assemblages from the Brissago granitic pegmatite, Western Southern Alps, Switzerland. Canad Mineral 46: 635-650

Websky M (1868) Über Sarkopsid und Kochelite, zwei neue Minerale aus Schlesien. Z Dtsch Geol Gesell 20: 245-257

WiSE MA, ČERNÝ P (1990) Beusite-triphylite intergrowths from the Yellowknife pegmatite field, Northwest Territories. Canad Mineral 28: 133-139

ŻELAŹNIEWICZ A (1987) Tectonic and metamorphic evolution of the Góry Sowie, Sudetes Mts, SW Poland. Ann Soc Geol Pol 57: 203-348

ŻELAŹNIEWICZ A (1990) Deformation and metamorphism in the Góry Sowie gneiss complex, Sudetes, SW Poland. Neu Jb Geol Paläont, Abh 179: 129-157

ŻELAźNIEwicz A (1997) The Sudetes as a Paleozoic orogen in central Europe. Geol Mag 134: 691-702 